2. To: (Receiving Organization)

Tank Waste Remediation

5. Proj./Prog./Dept./Div.:

W-519/Site Development/

Numatec Hanford Corp.

8. Originator Renarks:

For approval/release.

11. Receiver Remarks:

11A. Design Baseline Document?
3. From: (originating organization) Near Facility Monitoring

6. Design Authority/ Design Agent/Cog. Engr.:

R. M. Mitchell
4. Related EDT No.:

NA

7. Purchase Order No.:

NA

9. Equip./Companent No.:

NA

10. System/Bldg./Facility:

NA

12. Major Assm. Dwg. No.:

NA

13. Permit/Permit Application No.: NA

14. Required Response Date:

NA

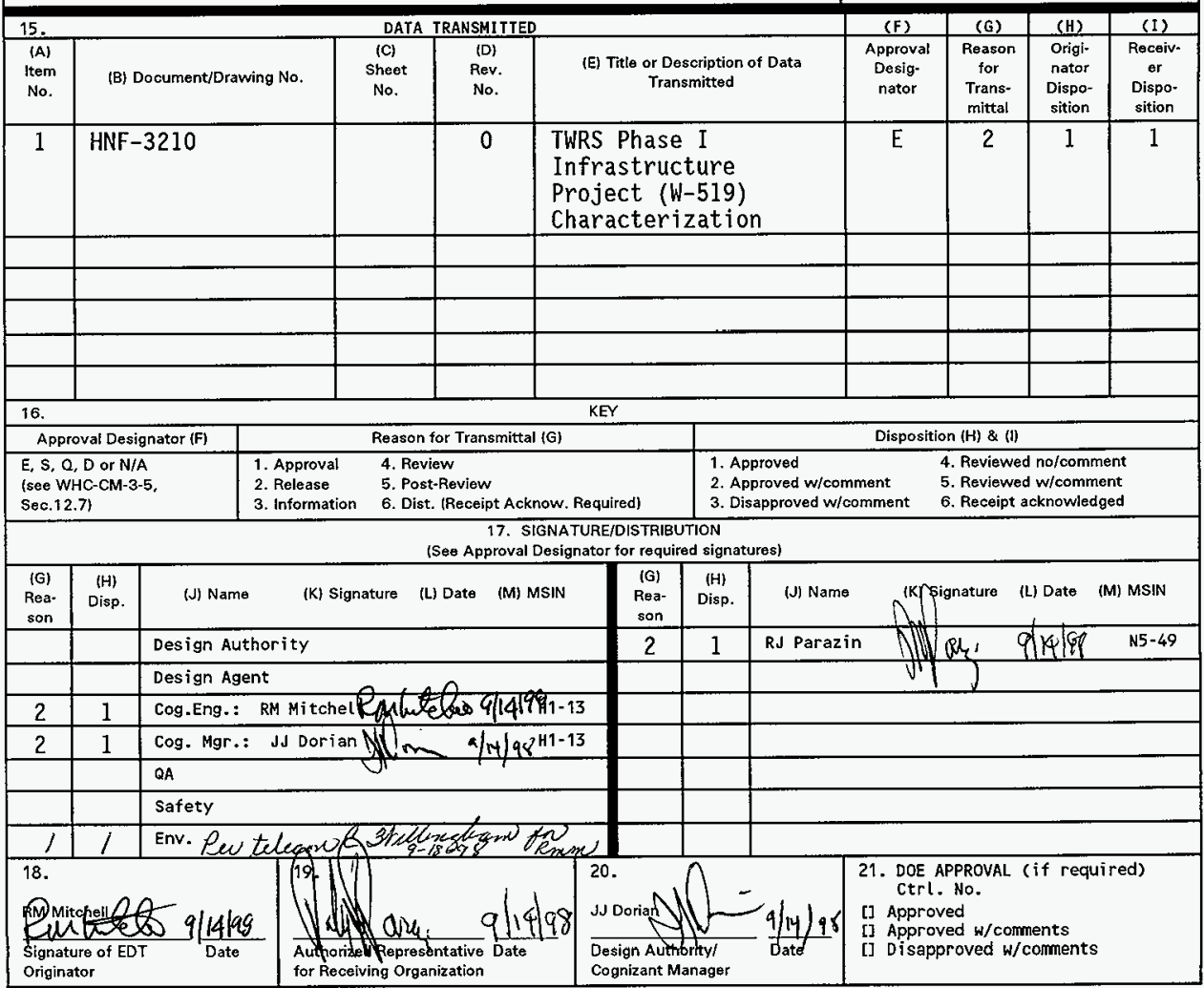

BD-7400-172-2 (05/96) GEF097 


\section{TWRS Phase I Infrastructure Project (W-519) Characterization}

R. M. Mitche11, B. M. Markes, D. E. Skoglie, and K. J. Young Waste Management Federal Services, Inc., Northwest Operations, T. M. Mitche11 CH2M Hill

Richland, WA 99352

U.S. Department of Energy Contract DE-AC06-96RL13200

EDT/ECN: EDT-622954 UC: 2070

Org Code: $03 E 00$

B\&R Code: EW3130010

Charge Code: D6350/HANA-1700

Tota7 Pages: $82 \mathrm{cw}_{q-15-98}$

Key Words: Soil, Augering, Characterization, Samples, W-519, Environmental

Abstract: This document provides a detaited description of the environmental samples collected for the TWRS (W-519) Infrastructure Characterization effort in and around the 200 East Area.

TRADEMARK DISCLAIMER. Reference herein to any specific comercial product, process, or service by trade name, trademark, manufacturer, or otherwise, does not necessarily constitute or imply its endorsement, recommendation, or favoring by the United States Government or any agency thereof or its contractors or subcontractors.

Printed in the United States of America. To obtain copies of this document, contact: Document Control Services, P.0. Box 950, Mailstop H6-08, Richland WA 99352, Phone (509) 372-2420.

Fax (509) 376-4989.
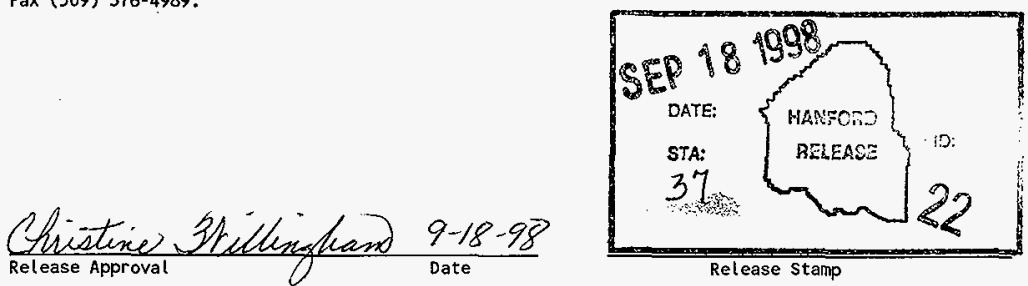

Release Stamp

\section{Approved for Public Release}




\title{
TWRS PHASE I INFRASTRUCTURE PROJECT (W-519) CHARACTERIZATION
}

\author{
R. M. Mitchell \\ B. M. Markes \\ D. E. Skoglie \\ K. J. Young \\ T. H. Mitchell
}




\section{CONTENTS}

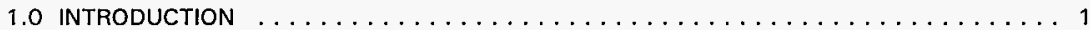

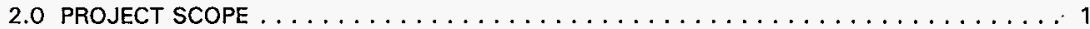

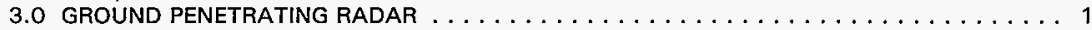

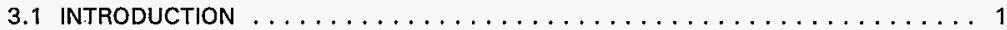

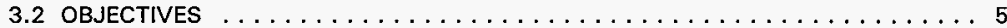

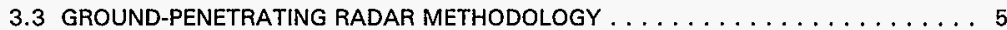

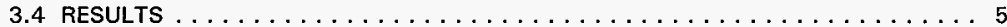

4.0 GLOBAL POSITIONING SYSTEM INFORMATION $\ldots \ldots \ldots \ldots \ldots \ldots \ldots$

4.1 GPR GRID LOCATIONS $\ldots \ldots \ldots \ldots \ldots \ldots \ldots \ldots \ldots \ldots \ldots \ldots \ldots \ldots$

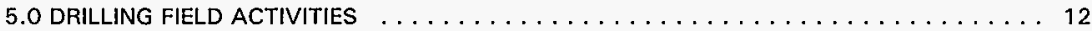

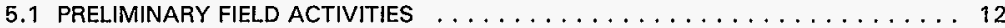

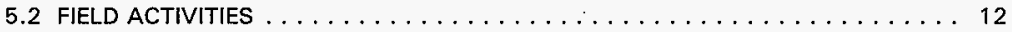

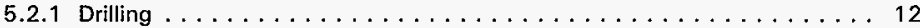

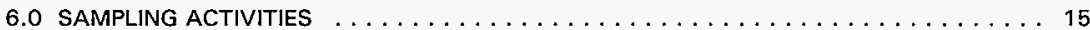

6.1 SAMPLING PREPARATION $\ldots \ldots \ldots \ldots \ldots \ldots \ldots \ldots \ldots \ldots \ldots \ldots \ldots$

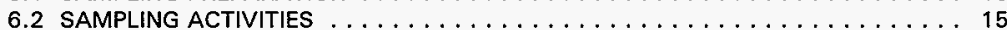

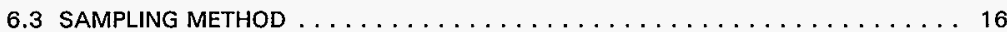

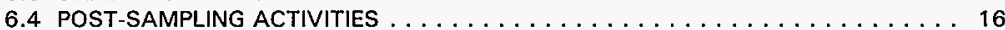

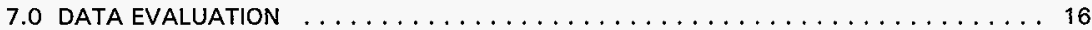

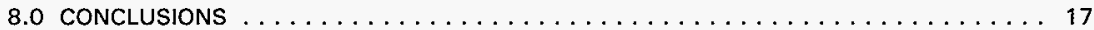

\section{Attachments}

A. Activity Hazard Analysis $\ldots \ldots \ldots \ldots \ldots \ldots \ldots \ldots \ldots \ldots \ldots \ldots \ldots \ldots \ldots \ldots \ldots$ A-i

B. Excavation Permit $\ldots \ldots \ldots \ldots \ldots \ldots \ldots \ldots \ldots \ldots \ldots \ldots \ldots \ldots \ldots \ldots$ B-i

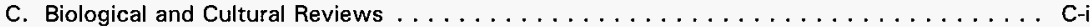

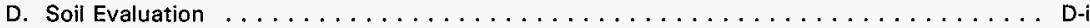

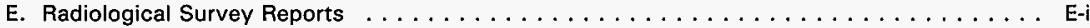

F. Start Card . . . . . . . . . . . . . . . . . . F

G. WSCF Analytical Laboratory Report $\ldots \ldots \ldots \ldots \ldots \ldots \ldots \ldots \ldots \ldots \ldots \ldots \ldots \ldots \ldots \ldots$

H. Sampling Logbook . ............................. 


\section{LIST OF FIGURES}

1. Map of Project $W-519$ Grid Sites and Sampling Locations . . . . . . . . . . . . 2

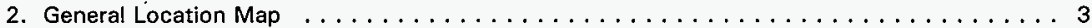

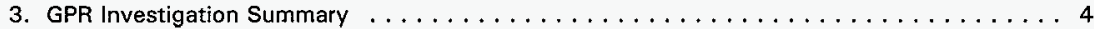

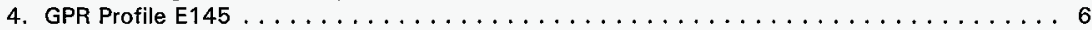

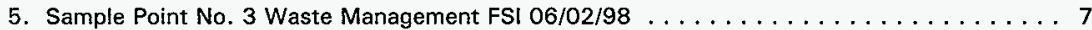

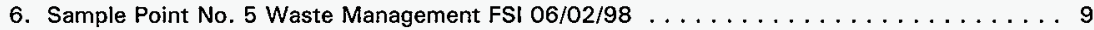

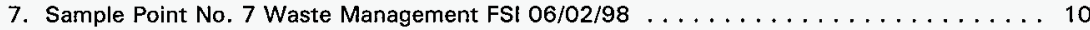

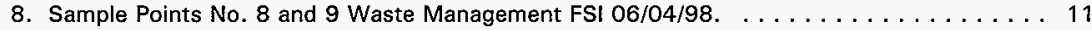

\section{LIST OF TABLES}

1. Corner Coordinates of GPR Grids for the Project W-519 Sample Locations . . . . . . 12

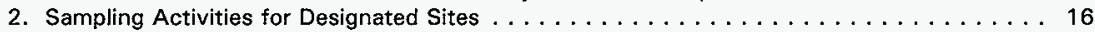

\section{LIST OF TERMS}

$\begin{array}{ll}\text { BLS } & \text { below land surface } \\ \text { COC } & \text { Chain of Custody } \\ \text { EPA } & \text { U.S. Environmental Protection Agency } \\ \text { GIS } & \text { Geographic Information System } \\ \text { GPR } & \text { Ground Penetrating Radar } \\ \text { GPS } & \text { Global Positioning System } \\ \text { GSSI } & \text { Geophysical Survey Systems Inc. } \\ \text { HPT } & \text { Health Physics Technician } \\ \text { NAD } & \text { North American Datum } \\ \text { NHC } & \text { Numatec Hanford Corporation } \\ \text { SIR } & \text { Subsurface Interface Radar (trademark of GSSI) } \\ \text { SOW } & \text { statement of work } \\ \text { TWRS } & \text { Tank Waste Remediation System } \\ \text { WMNW } & \text { Waste Management Federal Services, Inc., Northwest Operations } \\ \text { WSCF } & \text { Waste Sampling and Characterization Facility }\end{array}$


HNF-3210 Rev. 0

TWRS PHASE I INFRASTRUCTURE PROJECT (W-519) CHARACTERIZATION

\subsection{INTRODUCTION}

In order to treat the mixed radioactive and hazardous waste stored in 177 underground tanks, the Tank Waste Remediation System (TWRS) program is developing a "demonstration" site for treatment and immobilization of these wastes by a private contractor. Project $\mathrm{W}-519$ is providing the infrastructure support to this site by developing the designs and emplacing required pipelines, roads, electrical, etc. In support of the TWRS Phase I Infrastructure Project (W-519) Characterization, Numatec Hanford Corporation $(\mathrm{NHC})$ contracted with Waste Management Federal Services, Inc., Northwest Operations (WMNW) to investigate a number of locations in and just outside the 200 East Area eastern fenceline boundary. These areas consisted of known or suspected waste lines or waste sites that could potentially impact the construction and emplacement of the proposed facility improvements, including waterlines and roads. These sites were all located subsurface and augering would be required to obtain sample material from the desired depth. The soils would then be sampled and submitted to the laboratory for analysis of radioactivity.

\subsection{PROJECT SCOPE}

After reviews of the site, historical documents, and site maps, including a complete site walkdown, it was determined that five locations (see Figure 1; the numbers in brackets represent the original planning designations\} would be designated for augering and sampling. Field work was directed by a statement of work (SOW) developed by NHC personnel. At three of these locations, the site was staked out in a $50 \mathrm{ft}$ by $50 \mathrm{ft}$ grid marked off on $5 \mathrm{ft}$ centers. Sites $2(8)$ and 3 (9) were conducted along a single $30 \mathrm{ft} \times 200 \mathrm{ft}$ grid. Each location was subject to a Ground Penetrating Radar (GPR) survey. Each of the grids was permanently located using the Global Positioning System (GPS). One sample was collected from the desired depth ranging from $5 \mathrm{ft}$ to $8 \mathrm{ft}$ below existing grade. The samples were monitored by a Health Physics Technician (HPT), released, and submitted to the Waste Sampling and Characterization Facility (WSCF) laboratory for analyses of total alpha, total beta, and gamma spectroscopy.

\subsection{GROUND PENETRATING RADAR}

\subsection{INTRODUCTION}

WMNW provided a subcontract to $\mathrm{CH} 2 \mathrm{M}$ Hill to conduct GPR investigations of five sites in support of the TWRS Phase I Infrastructure Characterization (Figure 2). The five sites were where the soil was to be sampled using a drilling auger. Figure 3 is a summary of the investigation parameters. 
Figure 1. Map of Project W-519 Grid Sites and Sampling Locations.

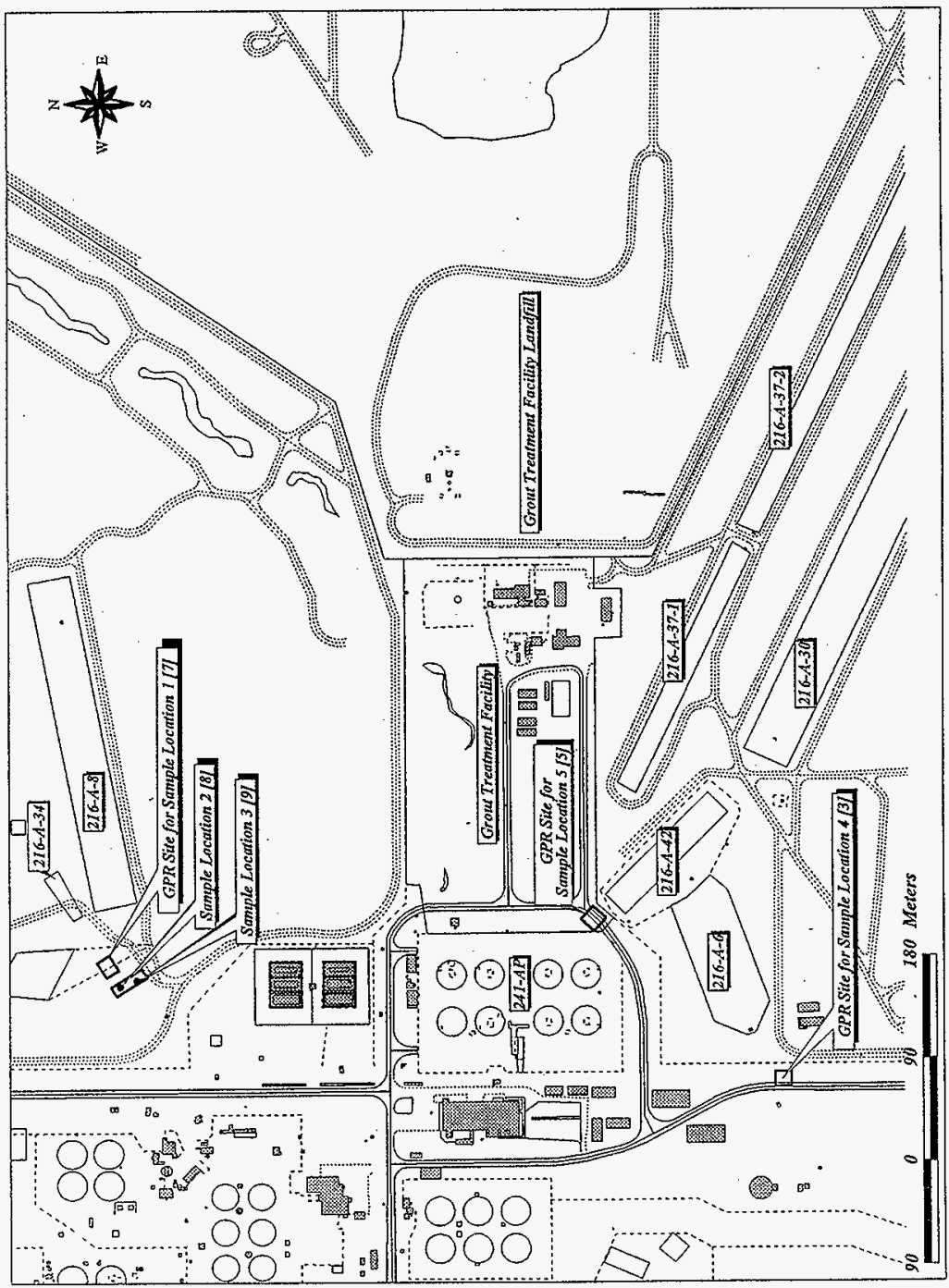


HNF-3210 Rev. O

Figure 2. General Location Map.

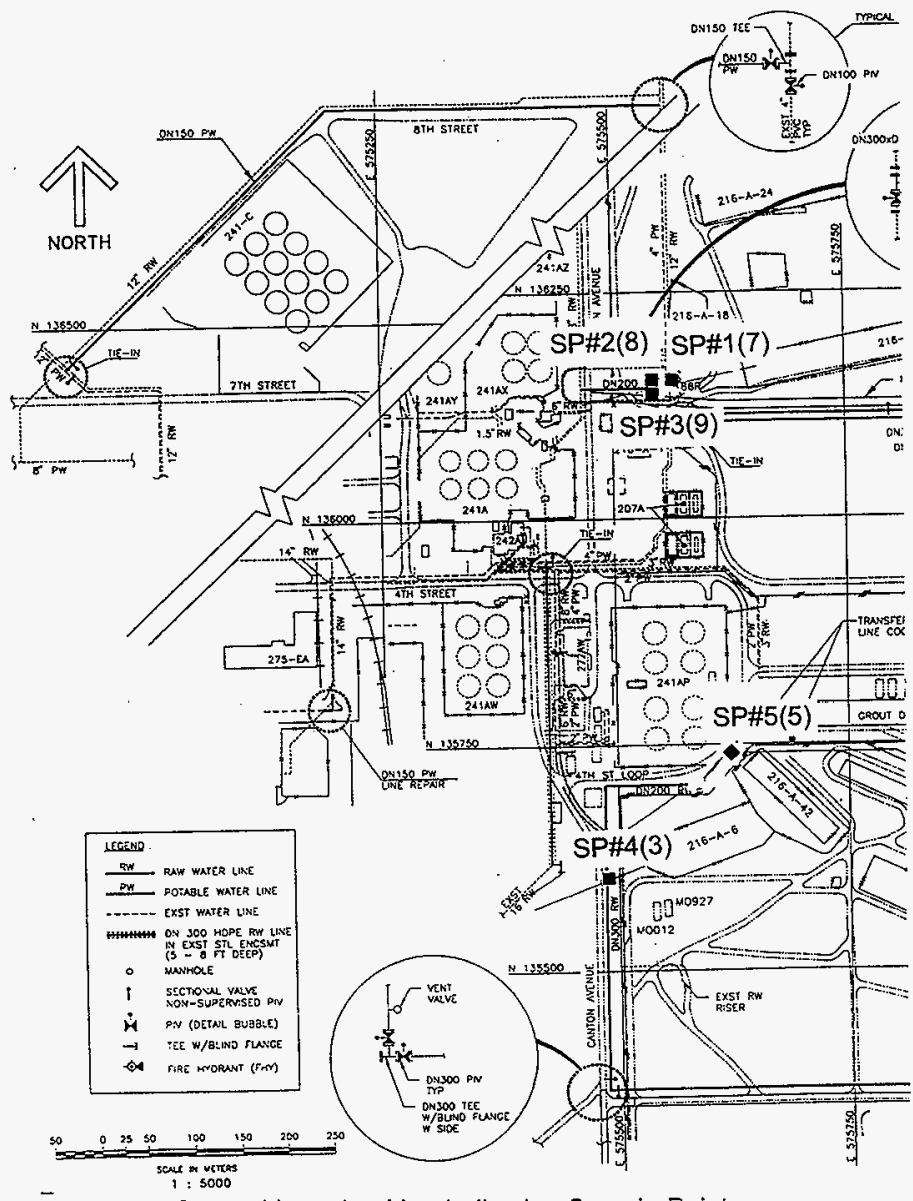


Figure 3. GPR Investigation Summary.

Sites: Sample Point \#3, Sample Point \#5, Sample Point \#7, Sample Point \#8, and Sample Point \#9.

Document Number: None

Date: June 1998

Sponsor (Contact, phone): Ron Mitchell (WMFSI) 509-376-5122

Investigators (Name, Company, Phone, E-mail): Tom Mitchell \& Kevin Bergstrom CH2M Hill

509-372-9690 (Thomas H Mitchell@RL.gov), 509-372-9591 (Kevin_A_Bergstrom@RL.gov)

Location: All in 200 East Area, Hanford Site, Richland, WA.

Sample Point \#3- East side of Canton Ave., south of 241-AP Tank farm

Sample Point \#5- Between 241-AP tank farm and 216-A-42 trench on $4^{\text {th }}$ Street.

Sample Point \#7- East of tank farm 241-AX and south of 216-A-24 crib, outside of the perimeter fence.

Sample Point \#8- East of tank farm 241-AX and south of 216-A-24 crib, outside of the perimeter fence.

Sample Point \#9- East of tank farm 241-AX and south of 216-A-24 crib, outside of the perimeter fence.

Objectives: To locate underground utilities, pipelines, or any other subsurface features that might impact the sampling with a cone penetrometer.

Cultural Resource Setting: NA

Site Description

Terrain:

SP\#3 - Flat gravel surface.

SP\#5 - Primarily flat asphalt with a $2-\mathrm{ft}$ deep ditch on the southeastern edge of the road and minor undulations immediately north of the road.

SP\#7- The grid is centered on a east-west trending 3-4-ft high berm. The crest is at ${ }^{-} \mathrm{N} 175$.

SP\#8- The grid is centered on a east-west trending 3-4-ft high berm. The crest is at - N175.

SP\#9- The grid is centered on a east-west trending 1-2-ft high berm. The crest is at $~-~ N 120$.

Vegetation:

SP\#3 - None

SP\#5 - None

SP\#7-Minimal, scattered tumble weed, cheat grass, and rabbit brush.

SP\#8- Minimal, scattered tumble weed, cheat grass, and rabbit brush.

SP\#9- Minimal, scattered tumble weed, cheat grass, and rabbit brush.

Hydro Properties (water table, moisture etc.):

All sites-Very dry, depth of investigation was entirely within the vadose zone.

Soil/sediments/rock type:

All sites - Eolian sand with scattered gravel/cobbles

Anticipated Bedrock (depth and type):

NA

Obstacles (rocks, trees, buildings etc):

SP\#3, 7,8 , and 9 - none

SP\# 5 - Steep 3-ft bank just outside the grid along E150.

Site limitations:

None

Overall assessment of site for geophysical investigations:

GPR was effective to depths of $0-10-\mathrm{ft}$ at all five sites.

Equipment:

Type/model: GSSI SIR1OA ground penetrating radar system. All data were collected with a GSSI 300 MHZ model 3105 antenna. All hard copies were made with a GS-608P Plotter.

Data format (tape/disk/hardcopy): Hard copies on file.

Survey Parameters/grid:

\section{Data Collection Parameters:}

A $5 \times 5$-ft grid was established at each site. Blue stakes were placed at the corner of each grid. Data were collected along parallel profiles spaced 5 feet apart in two orthogonal directions. WMFSI personnel surveyed the grids with a global positioning system (GPS).

Equipment Settings:

Range $108 \mathrm{~ns}$ : Scans/second- 25: Sample/scan 512

Continuous data collection: Signal gains and filtering were performed in the field. No post processing of the data was performed. 


\subsection{OBJECTIVES}

The primary objectives of the GPR investigation were:

- To locate and map subsurface utilities and other buried anthropogenic material that might interfere with the sampling.

- To identify alternative sites for sampling if the pre-selected sites had subsurface obstructions.

\subsection{GROUND-PENETRATING RADAR METHODOLOGY}

The GPR system for this work utilized a 300-megahertz $(\mathrm{MHz})$ transducer. The transducer transmits electromagnetic energy into the ground. Buried objects such as pipes, barrels, foundations, and buried wires can cause all, or a portion, of the transmitted energy to be reflected back towards a receiving antenna. Geologic features such as cross bedding, caliche horizons, paleosols, and clays can also cause reflections of the transmitted energy. The reflected energy provides the means for mapping the subsurface features of interest, whether man-made or geologic.

The maximum depth of investigation varies from site to site, and is a function of the transmit power, receiver sensitivity, frequency of the antenna, and attenuation of the transmitted energy. The attenuation of the energy is primarily a function of the local soil conditions. Depth of investigation is also affected by highly conductive material, such as metal drums and pipes, which essentially reflect all the energy. The method cannot "see" directly below areas of highly reflective material since "all" of the energy is reflected. The maximum depth for usabie data was about $14 \mathrm{ft}$ below the surface for these surveys.

Display and interpretation of GPR data are similar to that of seismic reflection data (i.e. data displayed as horizontal distance versus time, depicting pseudo cross-sections of the earth). Figure 4 is an example of a typical GPR profile, taken from the sample point \#3 site. The approach to an interpretation can be variable and influenced by the objectives of the survey and the experience of the interpreter. Numerous data processing techniques are available that may or may not aid in the interpretation process. In some areas, interpretations can be straight forward, but often a highly variable subsurface yields complex data that is difficult to interpret. The end product, in these surveys, is a plan view map showing the location and depth of features that were detected within the survey area.

The GPR data were collected with a Geophysical Survey Systems Inc. (GSSI) Subsurface Interface Radar (SIR) ${ }^{1}$ System $10 \mathrm{~A}$ Plus with a recording window of 108 nanoseconds, two-way travel time. A $300 \mathrm{MHz}$, model 3105 antenna was used.

\subsection{RESULTS}

Several linear anomalies were detected at the Sample Point \#3 site that have the characteristics of buried utilities or pipelines. The staked sample point was very near an east west trending linear (Figure 5). It was recommended that the sample point be moved a few feet to safely avoid the linear if the risk of inadvertent contact is important. Several isolated anomalies were also detected at Sample Point \#3. The majority of these anomalies were located in the northern and eastern portion of the survey grid and should be avoided if possible.

\footnotetext{
${ }^{1}$ A trademark of Geophysical Survey Systems Inc. (GSSI).
} 


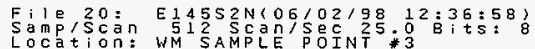

Mark SPacing: $5 F T$

Range: $N \perp 00$ TO N145

Position: $-10.0 \pi S$ Range: $108.0 \mathrm{nS}$

Range $G$ a i n -2 2 138 3 5160

$\checkmark$ (IIR $\mathrm{HP}=2 \mathrm{~F}=30$ )

HiIIR STK TC=3)

Table \#2; Transform \#1; Contrast s

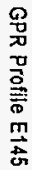

81.00

54.00

27.00

0.00

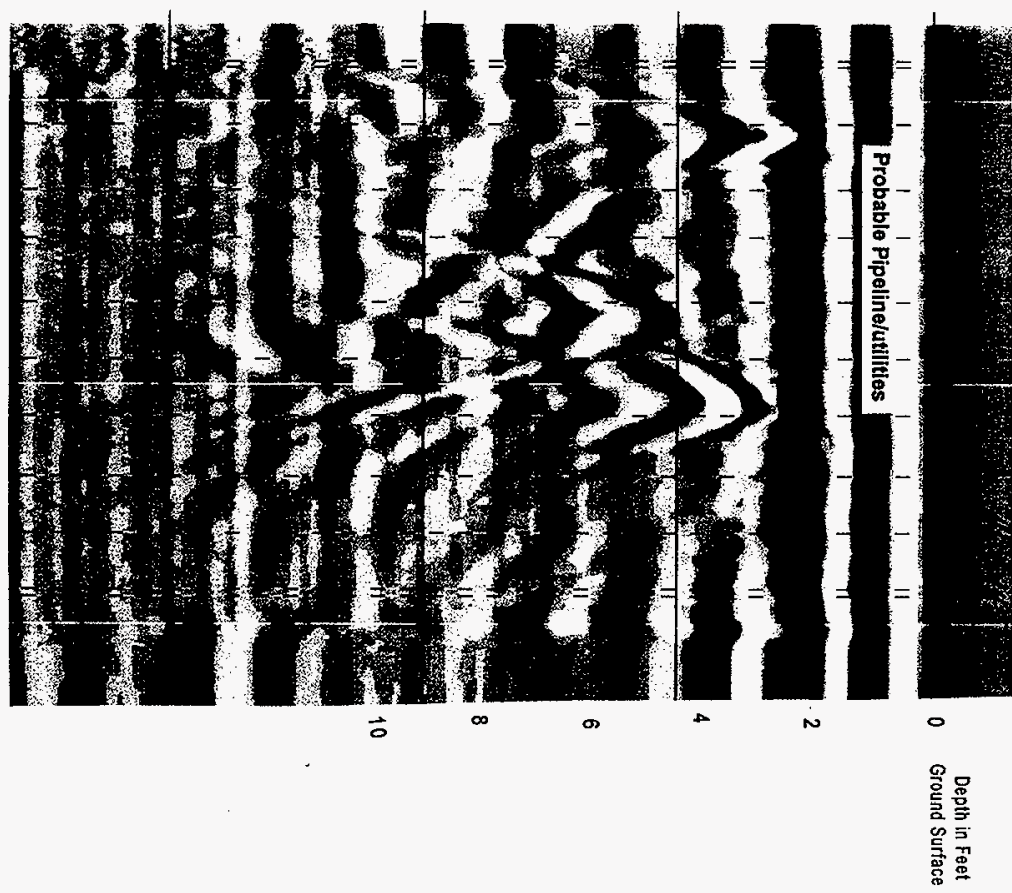

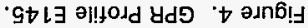


Figure 5. Sample Point No. 3 Waste Management FSI 06/02/98.

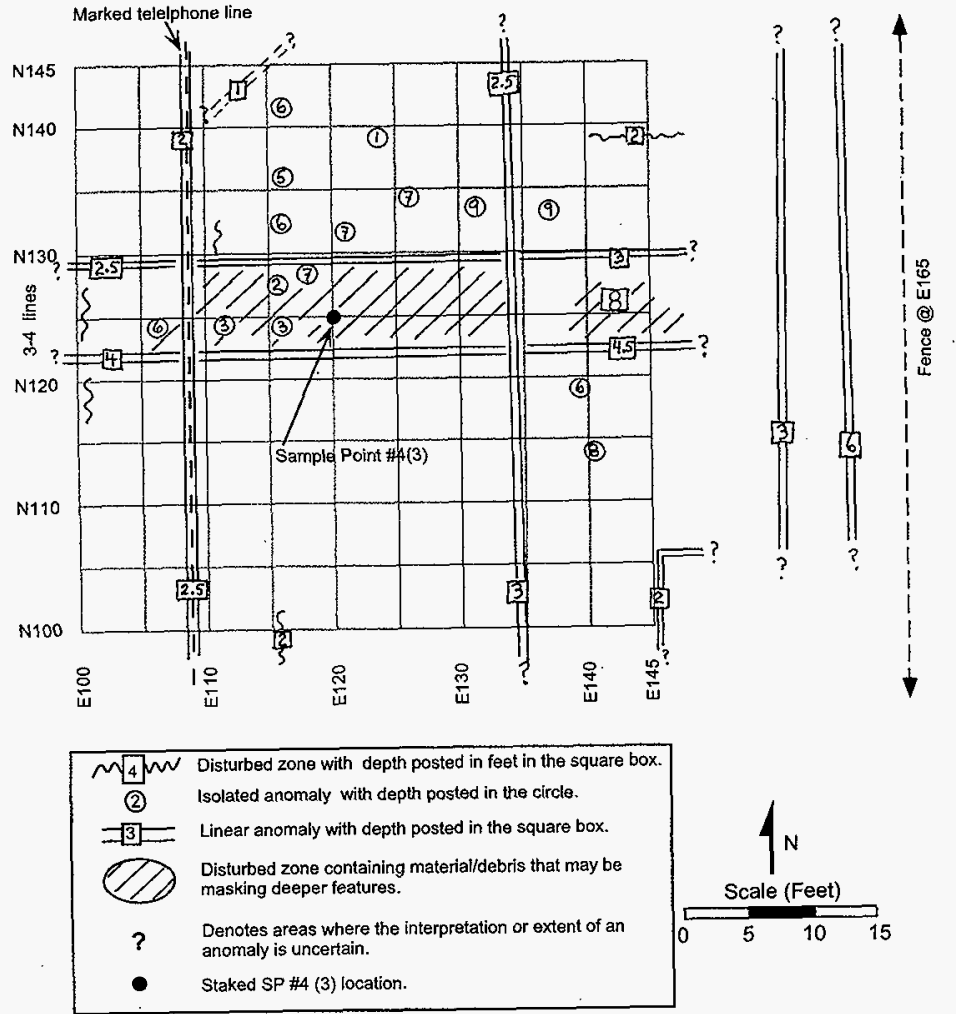


Figure 6 shows the results of the GPR survey at Sample Point \#5. Four distinct linears were identified. All linears, isolated anomalies, and disturbed zones should be avoided when selecting the final sample point if inadvertent contact is to be avoided.

Figure 7 shows the results of the GPR survey conducted at Sample Point \#7. The staked sample point was within $1-2 \mathrm{ft}$ to a linear anomaly that has the characteristics of a buried pipeline or utility.

A single grid system was used that incorporated both Sample Point \#8 and Sample Point \#9 (Figure 8). Two linears were detected, one near each sample point. Sample Point \#9 is in a disturbed zone that may contain anthropogenic material that could effect the sampling at the site.

\subsection{GLOBAL POSITIONING SYSTEM INFORMATION}

\subsection{GPR GRID LOCATIONS}

GPR operators using standard measuring techniques (i.e., tape measure) prepared the GPR grids. A global positioning system operator then collected geographic data pertaining to the corners of these grids using a survey quality GPS, capable of $2 \mathrm{~cm}(0.8 \mathrm{in}$.) accuracy in real time. These data were transferred to a personal computer with software designed to process and assess the quality of the GPS data. This software was also used to convert the raw GPS data into the Washington State Plane, North American Datum (NAD) 83-91 coordinate system as required by state and federal regulations. Once the data had been processed and approved, it was exported to an ASCII comma delimited file for use in conventional software programs (i.e., Microsoft ${ }^{2}$ Excel and Word) for reporting and to use in Geographic Information System (GIS) software to prepare scale maps of the GPR locations.

${ }^{2}$ Microsoft is a trademark of the Microsoft Corporation. 
Figure 6. Sample Point No. 5 Waste Management FSI 06/02/98.

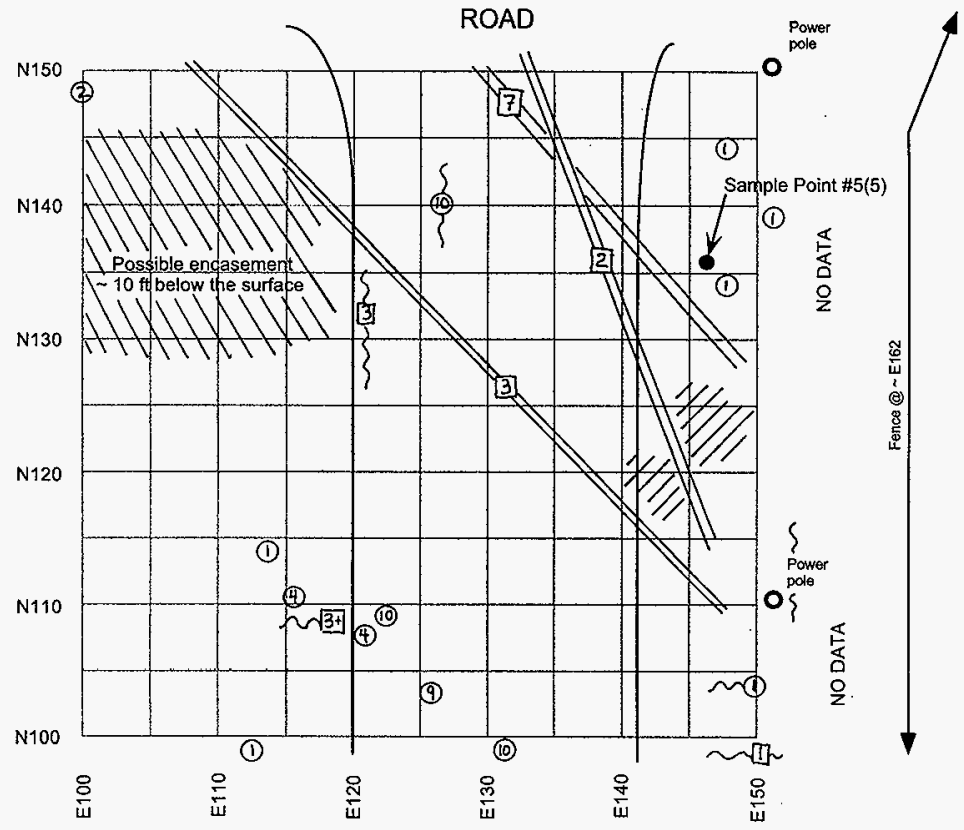
N 1 D Disturbed zone with depth posted in feet in the square box.
(2) Isolated anomaly with depth posted in the circle.
= Linear anomaly with depth posted in the square box.
Disturbed zone containing material/debris that may be masking deeper features.
? Denotes areas where the interpretation or extent of an anomaly is uncertain.
Staked SP \#5(5) location.

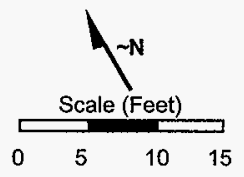


Figure 7. Sample Point No. 7 Waste Management FSI 06/02/98.

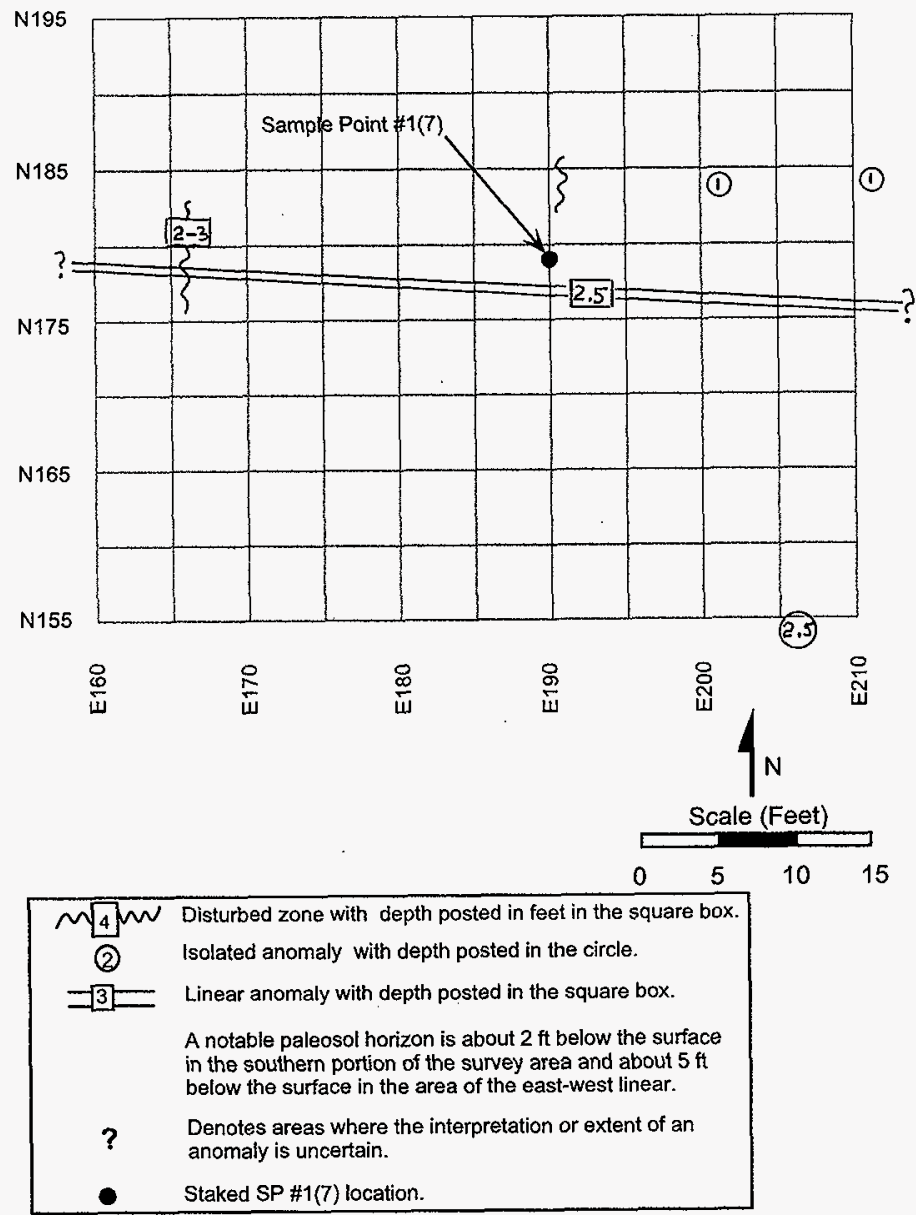


Figure 8. Sample Points No. 8 and 9 Waste Management FSI 06/04/98.

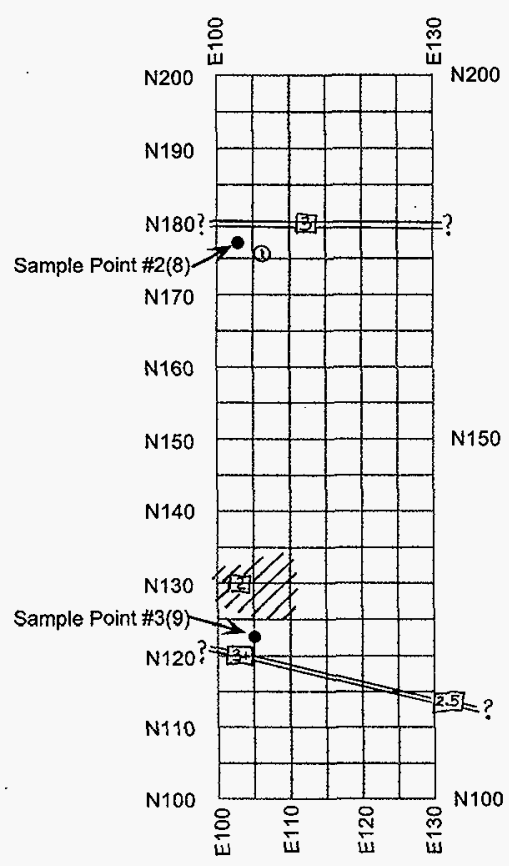

(2) Isolated anomaly with depth posted in the circle.

$=3$ Linear anomaly with depth posted in the square box.

Disturbed zone containing material/debris that may be masking deeper features.

? Denotes areas where the interpretation or extent of an anomaly is uncertain.

- Staked SP \#2(8) \& \#3(9) locations. 
Table 1. Corner Coordinates of GPR Grids for the Project W-519 Sample Locations.

\begin{tabular}{|c|c|c|c|c|}
\hline Site No. & Point ID & Easting & Northing & Elevation \\
\hline 1 & 1 & 575560.156 & 136165.175 & 203.025 \\
\hline 1 & 2 & 575567.882 & 136170.058 & 202.488 \\
\hline 1 & 3 & 575584.233 & 136144.413 & 202.065 \\
\hline 1 & 4 & 575576.433 & 136173.808 & 202.565 \\
\hline 2,3 & 5 & 575576.569 & 136139.461 & 202.409 \\
\hline 2,3 & 6 & 575589.335 & 136182.020 & 202.260 \\
\hline 2,3 & 7 & 575595.842 & 136171.785 & 202.039 \\
\hline 2,3 & 8 & 575583.026 & 136163.537 & 202.132 \\
\hline 4 & 9 & 575615.349 & 135756.334 & 208.139 \\
\hline 4 & 10 & 575625.418 & 135767.738 & 208.029 \\
\hline 4 & 11 & 575636.878 & 135757.672 & 207.782 \\
\hline 4 & 12 & 575626.774 & 135746.282 & 207.741 \\
\hline 5 & 13 & 575478.996 & 135602.698 & 214.656 \\
\hline 5 & 14 & 575492.665 & 135602.629 & 214.335 \\
\hline 5 & 15 & 575492.639 & 135588.958 & 214.709 \\
\hline 5 & 16 & 575478.987 & 135589.015 & 214.942 \\
\hline
\end{tabular}

\subsection{DRILLING FIELD ACTIVITIES}

\subsection{PRELIMINARY FIELD ACTIVITIES}

Field inspections were completed prior to on-site drilling activities. Prior to initiating field work, excavation permits, cultural and biological resource reviews, start cards, etc. were obtained (see Attachments A through $\mathrm{H}$ ). These field inspections provided information supporting preliminary documentation and planning.

Boring designations were obtained for five (5) geotechnical borings (B8701 through $B 8705$ ).

\subsection{FIELD ACTIVITIES}

\subsubsection{Drilling}

Drilling commenced on June 10, 1998 and was completed on June 11, 1998. A SIMCO model 2400 auger drill (gasoline over hydraulic) was used in conjunction with 8 in. O.D. solid stem augers. 
The following describes boring reference numbers:

1. Site 1, B8701 (boring designation), planning number 7 ;

2. $\quad$ Site 2, B8702 (boring designation), planning number 8 ;

3. Site 3, B8703 (boring designation), planning number 9;

4. Site 4, B8704 (boring designation), planning number 3; and

5. Site 5, B8705 (boring designation), planning number 5 .

Drilling details such as duration, sample times, and methods were documented in the Samplers Logbook (reference WM-SML-H13). A discussion on site specific operations is as follows:

1. Site 4 (sample point 3, B8704): June 10, 1998. A Pre-Job Safety meeting was held; the auger unit was set-up and drilling initiated at 08:50; an auger flight was added to the drill string at 09:04; sample depth achieved $(7 \mathrm{ft}$ below land surface [BLSI] at 09:08; drilled to a depth of $8 \mathrm{ft} \mathrm{BLS}$ and a sample obtained (09:18) by pulling flights up. Sample interval $7 \mathrm{ft}$ to $8 \mathrm{ft}$ BLS.

A soil change was noted from $6 \mathrm{ft}$ to $8 \mathrm{ft}$ BLS. The soil change consisted of a washed medium/coarse grained sand.

Upon removal of the auger flights, the boring was backfilled and slightly compacted with previously excavated (drilled) soil. The flag locator was placed at the boring location.

No contamination was noted with field instrumentation. Background was noted at $100 \mathrm{cpm} /$ PA Beta/Gamma.

Visitors on location were Mr. William Hopkins and Mr. Ted Perry with the water utilities department. The Water utilities personnel viewed drilling operations at Site 4 , since a water line was located to the East of the boring location.

The sampling Team consisted of Mr. Karl Hulse (Scientific Technician), Mr. Laurence Corgatelli (Health Physics Technician), Mr. Ron Mitchell (Project Manager) and Mr. Dave Skoglie (Drilling Engineer).

2. The Original plan was to drill boring B8705 (Site 5, sample point 5); however, the electrical utilities planning department could not fit us in their schedule for the 10th of June. Prior arrangements had been made with the utilities department. Electrical utilities will turn-off power to RO600 2,400 volt lighting line) the 11th at 08:00.

Site 3 (sample point 9, B8703): The auger unit was set-up and drilling initiated at 10:15; sample depth achieved (4 ft BLS) at 10:20; drilled to a depth of $5 \mathrm{ft} \mathrm{BLS}$ and a sample obtained (10:23) by pulling flights up. Sample interval $4 \mathrm{ft}$ to $5 \mathrm{ft}$ BLS.

A soil change was noted from $\sim 4 \mathrm{ft}$ to $5 \mathrm{ft}$ BLS. The soil change consisted of a light colored fine grained sand.

Upon removal of the auger flights, the boring was backfilled and slightly compacted with previously excavated (driled) soil. The flag locator was placed at the boring location.

No contamination was noted with field instrumentation. Background was noted at $100 \mathrm{cpm} / \mathrm{PA}$ Beta/Gamma.

No visitors were on location. 
The sampling Team consisted of Mr. Karl Hulse (Scientific Technician), Mr. Laurence Corgatelli (Health Physics Technician), Mr. Ron Mitchell (Project Manager) and Mr. Dave Skoglie (Drilling Engineer).

3. Site 2 (sample point 8, B8702): The auger unit was set-up and drilling initiated at 10:37; sample depth achieved (4 ft BLS) at 10:42; drilled to a depth of $5 \mathrm{ft} \mathrm{BLS}$ and a sample obtained $(10: 45)$ by pulling flights up. Sample interval $4 \mathrm{ft}$ to $5 \mathrm{ft} \mathrm{BLS}$.

A soil change was noted from $\sim 4 \mathrm{ft}$ to $5 \mathrm{ft}$ BLS. The soil change consisted of a light colored fine grained sand.

Upon removal of the auger flights, the boring was backfilled and slightly compacted with previously excavated (drilled) soil. The flag locator was placed at the boring location.

No contamination was noted with field instrumentation. Background was noted at $100 \mathrm{cpm} / \mathrm{PA}$ Beta/Gamma.

No visitors were on location.

The sampling Team consisted of Mr. Karl Hulse (Scientific Technician), Mr. Laurence Corgatelli (Heaith Physics Technician), Mr. Ron Mitchell (Project Manager) and Mr. Dave Skoglie (Drilling Engineer).

4. Site 1 (sample point, B8701): The auger unit was set-up and drilling initiated at 10:50; sample depth achieved (5 ft BLS) at 11:01; drilled to a depth of $5 \mathrm{ft}$ BLS and a sample obtained $(11: 04)$ by pulling flights up. Sampling interval $5 \mathrm{ft}$ to $5.75 \mathrm{ft}$ BLS.

A soil change was noted from $~ " 5 \mathrm{ft}$ to $5.75 \mathrm{ft} \mathrm{BLS}$. The soil change consisted of a light colored fine-grained sand.

Upon removal of the auger flights, the boring was backfilled and slightly compacted with previously excavated (drilled) soil. The flag locator was placed at the boring location.

No contamination was noted with field instrumentation. Background was noted at $100 \mathrm{cpm} /$ PA Beta/Gamma.

No visitors were on location.

The sampling Team consisted of Mr. Karl Hulse (Scientific Technician), Mr. Laurence Corgatelli (Health Physics Technician), Mr. Ron Mitchell (Project Manager) and Mr. Dave Skoglie (Drilling Engineer).

5. Site 5 (sample point 5, B8705): June 11, 1998. The Electricians met with Mr. Skoglie at the breaker location in 200 East. The Electricians de-energized the RO600 lighting line and tagged out the system. Mr. Skoglie notified the dispatcher and overtagged the system. The electricians viewed the boring location and verified the lighting line.

The auger unit was set-up and drilling initiated at 08:27; an auger flight was added to the drill string, sample depth achieved ( $5 \mathrm{ft} \mathrm{BLS}$ ) at 08:41; drilled to a depth of $6 \mathrm{ft} \mathrm{BLS}$ and a sample obtained (08:50) by pulling flights up. Sampling interval $5 \mathrm{ft}$ to $6 \mathrm{ft} \mathrm{BLS}$. 
A soil change was noted from $~ 5 \mathrm{ft}$ to $6 \mathrm{ft}$ BLS. The soil change consisted of a light colored fine-grained sand.

Upon removal of the auger flights, the boring was backfilled and slightly compacted with previously excavated (drilled) soil. The flag locator was placed at the boring location.

No contamination was noted with field instrumentation. Background was noted at $100 \mathrm{cpm} / \mathrm{PA}$ Beta/Gamma.

No visitors were on location. However, adjacent to the work location were two operators watching the sampling operation ( $08: 35$ ). No comments were made to Mr. Hulse whom initiated discussions with the Operators.

The sampling Team consisted of Mr. Karl Hulse (Scientific Technician), Mr. Laurence Corgatelli (Health Physics Technician), and Mr. Dave Skoglie (Drilling Engineer).

\subsection{SAMPLING ACTIVITIES}

\subsection{SAMPLING PREPARATION}

In support of Phase 1 Privatization Site Infrastructure (W-519) sampling containers and laboratory provided Petri dishes meeting U.S. Environmental Protection Agency (EPA) Level 1 cleanliness guidelines were selected for this project. Each container had been bar coded with a lot and serial number (provided by the manufacturer). Certificates of analysis verifying the cleanliness of the containers by lot are maintained by Sampling Services in accordance with SML-EP-001, Section 1.3, "Control of Certificates of Analysis." Types of containers and lot numbers are listed in the field logbook (WM-SML-H13, pages 77-82) and are contained in this document (Attachment $H$ ).

The work plan for Phase 1 Privatization Site Infrastructure specified that stainless steel sampling equipment be cleaned in accordance with SML-EP-001, 2.5, Rev. 0 "Laboratory Cleaning of Sampling Equipment." All stainless steel bowls and spoons were cleaned to this procedure prior to deployment to the field.

\subsection{SAMPLING ACTIVITIES}

Sampling activities were conducted at the designated sites from June 10-11, 1997. Sampling was performed in accordance with SML-EP-001, 4.1, Rev. 0, "Soil and Sediment Sampling." A list of the sample site locations, corresponding sample identification numbers, collection dates and times, and the analytical laboratory are provided below. 
Table 2. Sampling Activities for Designated Sites.

\begin{tabular}{|c|l|l|l|l|l|l|}
\hline Sample \# & $\begin{array}{c}\text { Sample } \\
\text { Site }\end{array}$ & \multicolumn{1}{|c|}{ Borehole \# } & $\begin{array}{c}\text { Sample } \\
\text { Depth }\end{array}$ & Date & Time & Lab \\
\hline S8091-01 & $1[7]$ & B8701 & $5 \mathrm{ft}-6 \mathrm{ft}$ & $6-10-98$ & 1104 & WSCF \\
\hline S8091-02 & $2[8]$ & $\mathrm{B} 8702$ & $4 \mathrm{ft}-5 \mathrm{ft}$ & $6-10-98$ & 1045 & WSCF \\
\hline S8091-03 & $3[9]$ & $\mathrm{B} 8703$ & $4 \mathrm{ft}-5 \mathrm{ft}$ & $6-10-98$ & 1023 & WSCF \\
\hline S8091-04 & $4[3]$ & $\mathrm{B} 8704$ & $7 \mathrm{ft}-8 \mathrm{ft}$ & $6-10-98$ & 0918 & WSCF \\
\hline S8091-05 & $5[5]$ & B8705 & $5 \mathrm{ft}-6 \mathrm{ft}$ & $6-11-98$ & 0850 & WSCF \\
\hline
\end{tabular}

WSCF $=$ Waste Sampling and Characterization Facility.

A map of sample locations are in the Field logbook (WM-SML-H13, pages 77-82) and are attached to this document (Attachment $\mathrm{H}$ ).

\subsection{SAMPLING METHOD}

A SIMCO model 2400 auger drill with a 8 in. outside diameter solid stem auger was used to reach the desired sample depth. When the Auger reached the sample depth the auger was raised the flights were cleaned of soil and the auger was lowered back into the hole and drilled an additional foot. The auger was then raised were the sample was collected from the lower flights with a cleaned stainless steel spoon and bowl. wet ice.

Samples were shipped to the WSCF by government vehicle in a sealed ice chest, packed on

\subsection{POST-SAMPLING ACTIVITIES}

Chain of Custody (COC) \#101078 was used to maintain custody on all samples and maintained in accordance with SML-EP-001, 1.1, "Chain of Custody/Sample Analysis Request." The $\mathrm{COC}$ was maintained from the sample collection site through delivery of the samples to the Laboratory. Samples were delivered to the laboratory on the final day of collection. Samples from the previous day were stored overnight in a refrigerated custody locked storage area (6269 Building) maintained by Sampling Services.

Field logbook WM-SML-H13 was used in accordance with SML-EP-001, 1.5, "Field Logbooks" to document all sampling activities.

\subsection{DATA EVALUATION}

Analytical data were received form the WSCF laboratory and the complete data set is included in Attachment $G$. All of the values for total alpha and total beta were below the minimum detection limits for the laboratory and showed up as "undetected" by the result qualifier.

For the gamma spectroscropy, all of the radioanalytes were below the minimum detection limits and were designated as "undetectable," with the exception of ${ }^{134} \mathrm{Cs}$. However, the WSCF lab has since determined that the reported ${ }^{134} \mathrm{Cs}$ values are invalid and represent naturally-occuring 
radionuclides, such as thorium. Therefore, no radionuclides were detected in the samples above the detection limits. The average value reported for ${ }^{137} \mathrm{Cs}$ in the 200 Area surface soils for the near-facility monitoring in 1997 was $1.8 \mathrm{E}+00 \mathrm{pCi} / \mathrm{g}$.

\subsection{CONCLUSIONS}

Based on the results of the field characterization efforts and analytical data, some general conclusions can be made regarding the project locations investigated. The data collected represent a good "snapshot" of conditions where a high probability of radioactive contamination would have been expected. However, sampling methods by their very design do not provide detailed information on every aspect of the proposed site. Unanticipated field conditions during construction can occur and should probably be expected within the 200 Areas where 50 years of waste operations activities, changing environmental conditions, and current cleanup operations affect these sites on a daily basis. The conclusions reached to date include the following:

- There should be limited potential for contamination at the proposed construction depth inside a 3 to $5 \mathrm{ft}$ radius from identified structures where boreholes were completed.

- The above statement is an extrapolation of evidence from previous studies on the 200 Areas plateau of the Hanford Site that indicate that leaks, spills, etc., generally move through the sandy soils in a roughly spherical pattern. Localized soil anomalies, however, could be expected to affect this process.

- Data from a single borehole which indicates a lack of contamination at, or near, a known disposal site should not be construed to mean that the site is entirely free of contamination.

- The borehole location represents only one of the four compass points around any particular underground facility. This should be kept in mind during construction planning.

- Comprehensive health and safety guidelines should be delineated for workers included in construction activities, with special consideration given to any and all areas around the boreholes investigated during this study, or to any other underground structures or utilities.

- Any of the above conclusions can be obviated by anomalous conditions not encountered during the characterization study, by ongoing or new construction or operational activities which may impact the proposed route, and by constantly changing environmental conditions which could affect the movement of contaminants away from the waste site during the period from finalization of this characterization effort to project completion. 
HNF-3210 Rev. 0

This page intentionally left blank. 
HNF-3210 Rev. 0

Attachment A.

Activity Hazard Analysis. 
HNF-3210 Rev. O

This page intentionally left blank. 
vision of Work rackage: 0

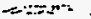

$\therefore$ Page 1 of 2

PRE-JÖB BRIEFING FORM

Description/Title:

ग rk Package Number:

rson in Charge:

W-519 AUGER SAMPLING
R.519
RON Matchell

mes of First Aid Qualified Person(s):

Dave skoglie

leck Ittems Discussed:

J Required Design Documents are Complete?

F/Procedures/Plans to be Used

I Applies OSR's

7 Radiation Work Permit

1. Activity hazard Analysis, SS HASP

₹. Construction Permit (as needed)

Additional Permits (i.e., confined space, excavation, etc.)

No. $\frac{N / A}{N A}$
No.
No. $\frac{N A}{98-008}$
No.

No. $\frac{98-008}{N / A}$

No. JAN 1067

7 Review all Applicable Safety Precautions and Prestart Conditions per Procedures/Plans to be used

I Components Locked and Tagged (Job Specific Work Instnuctions and Look and Tag Signature Sheet will be issued if Lock and Tag is applicable

7 AlARA Considerations (applicable MSDS's)

4 Respiratory Protection (fresh air, PAPR's, chemical filters, etc.) $N / A$

4 Radioactive Contamination Containment Device $\mathrm{Ni \textrm {A }}$.

[ L E Emergency Response and Actions

17 Summary of Job Sequence (or steps)

I Work Area Conditions (high/low temperatures, lighting, proper equipment location, pinch points, etc.)

. All Equipment Functionally Checked and at Work Site

JTHER TOPTCS Electrical-A lighting line will be turned off and wMN hang (over tag) a DAnGER TAG.

SONCERNS: Radiological contamiation is a jessbility Bio logicial hajards mity also be present.

TRAINING: (Initial)

7 Field Superintendent, or Alternate, VERIFY TRAINING OF AUX PERSONNELX

CONDUCTING TASKS IS CURRENT FOR BOTH MANDATORY TRAINING AND

DIRECTED (TASK SPECIFIC) TRAINING. Directed (Task specific) iraining for example is Basic Crant \& Rigging, or .

- Advanced Crane \& Rigging for personnel using cranes/hoists.

\section{SIGNATURE:}

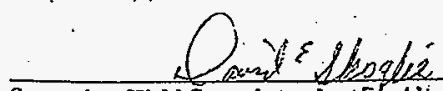

Supervisor/Field Superintendent, Gor Alternate 
HNF-3210 Rev. 0

ZE-JOB BRIEFING FORM (Continued)

$\rightarrow$

Page 2 of 2

ATTENDANCE ROSTER

ITRE WORK PACKAGE REVIEWED ALONG WTH CURRENI RWP'S.

eckname off on attached list. $A D D$ rame to list if not listed.

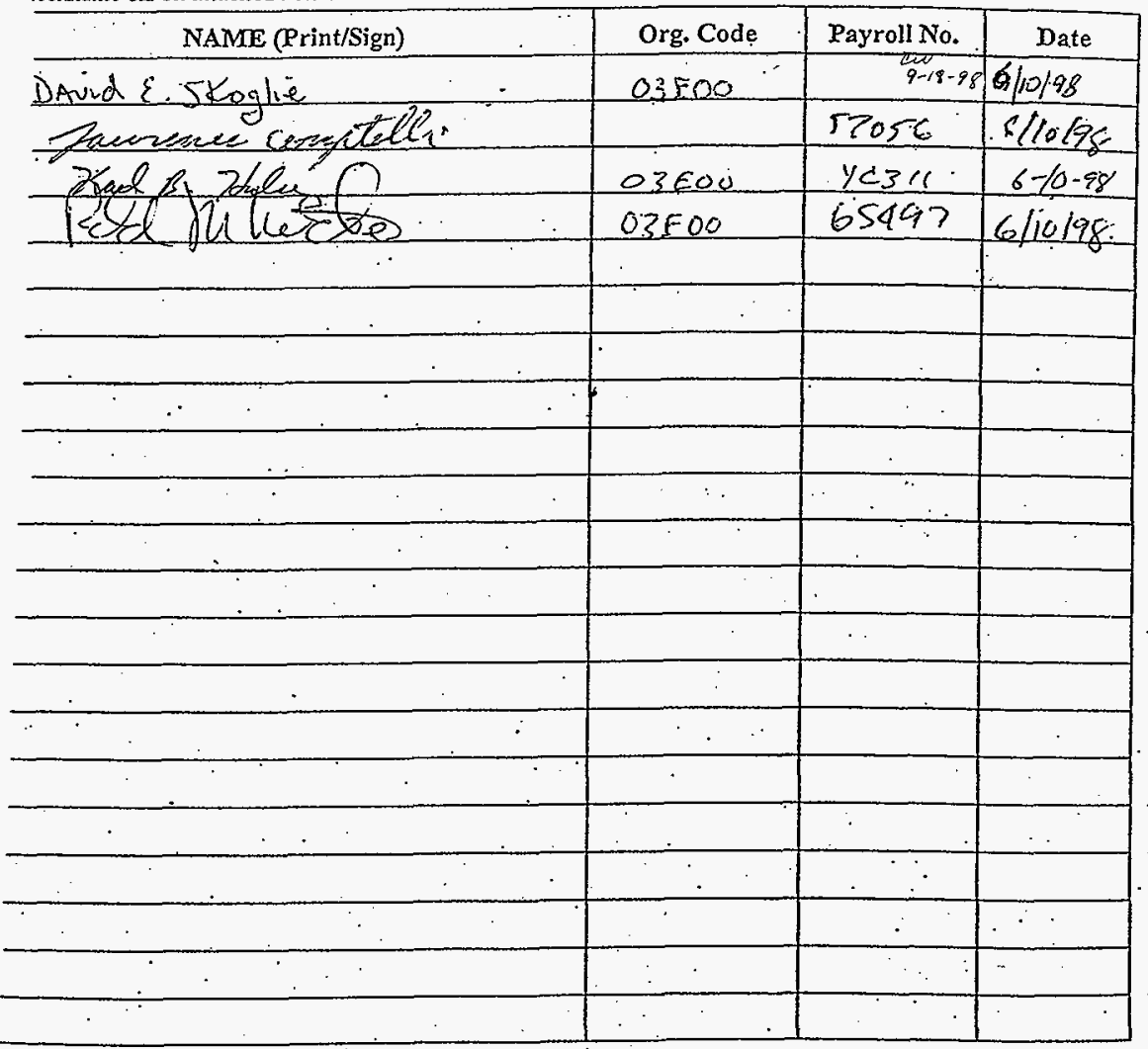




\begin{tabular}{|c|c|c|c|c|c|}
\hline Site/Activity Name: & \multicolumn{3}{|c|}{ W-SI9 PRIVATIZATION STTE INFRASTRUCTURE SAMPLING } & \multicolumn{2}{|l|}{ AHA NUMBER: $98-008$} \\
\hline Job Site Location: & \multicolumn{5}{|c|}{200 EAST AND RMMEDLTE AREA. } \\
\hline Field Task Lead: & \multicolumn{2}{|l|}{ RON MTTCHELL } & Ahemate: & \multicolumn{2}{|l|}{ DAN EDWARDS } \\
\hline Field Superintendent: & \multicolumn{2}{|l|}{ BOB JONES } & Alternate: & \multicolumn{2}{|l|}{ DAVE SKOGLEE } \\
\hline Safety Representative: & \multicolumn{2}{|l|}{ MIKE MADISON } & Altemate: & \multicolumn{2}{|l|}{ MARTY GARDNER } \\
\hline \multicolumn{6}{|l|}{ APPROVALS: } \\
\hline $\begin{array}{l}\text { Name - Field Superisten } \\
\text { Field Team Leader }\end{array}$ & E. 8120140 & $5 / 12 / 98$ & Neview) & Palth Erofessional (Independent & $5 / 12 / \varepsilon 8$. \\
\hline \multicolumn{6}{|c|}{ 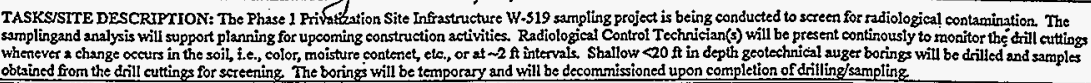 } \\
\hline
\end{tabular}

\begin{tabular}{|c|c|c|c|c|c|c|c|c|}
\hline \multicolumn{9}{|c|}{$\begin{array}{l}\text { FAAZARD ANALYSIS } \\
\text { Check below all ttems applicable to Job or task being camied out }\end{array}$} \\
\hline & Yes & No & & Yes & No & & Yes & No \\
\hline Electiol & . $x$ & & Noise & $x$ & & Respiratory Hazards & & $x$ \\
\hline Material Handling & & $x$ & Dust & $x$ & & Lock \& Tag & & $x$ \\
\hline Heavy Equipment & & $\mathbf{x}$ & Temperature Extremes & $x$ & & Pressure Systems & & $\mathbf{x}$ \\
\hline Manual Lifting & $\mathrm{x}$ & & Illumination & & $\mathrm{x}$ & Explosives & & $x$ \\
\hline Elevated Work & & $x$ & Chemicals & $x$ & & Grinding/S2wing & . $\cdot$ & $\mathbf{x}$ \\
\hline Pinch Points & $x$ & & Biologieal Hazards & $x$ & & Compressed Air & & $\mathrm{x}$ \\
\hline Power Tools & & $\mathbf{x}$ & Radiological Hazards & $x$ & & LPG & & $\mathbf{x}$ \\
\hline Compressed Gas Cylinder & & $\mathbf{x}$ & Asbertos & & $x$ & Portable Heaters & & $x$ \\
\hline Welding \& Cutting & & $x$ & Scaffolding & & $x$ & Egress Means & & $x$ \\
\hline Steam & & $x$ & Subsidance & & $x$ & Sharp Objects & $x$ & \\
\hline Hot Surfaces & $\cdot$ & $x$ & Confined Space & & $x$ & Cryogenies & & $x$ \\
\hline Iadders & & $x$ & Water Hazards & & $\mathbf{x}$ & Ventifation . & & $\mathbf{x}$ \\
\hline Walking/Working Surfaces & $x$ & & Remole Work Area & & $x$ & Fhying Objects & & $\mathrm{x}$ \\
\hline Exeavation & $x$ & & Cranes/Rigging & & $x$ & Powered Ind. Trucks & & $\mathbf{x}$ \\
\hline Vehicle Traffic & & $\mathrm{x}$ & Drilling & $x$ & & Guarding & $x$ & \\
\hline Overtead Hazards & $\mathrm{x}$ & & Spill Containment & & $\mathbf{x}$ & Hand Toois & $x$ & \\
\hline Falling Objects . & $\mathrm{x}$ & & Sign/Site Control & $x$ & & Man Baskets & & $x$ \\
\hline Sanitation & $x$ & & OffRoad Vehicle Use & v & $x$ & First Aid & $\mathrm{x}$ & \\
\hline Hazard Communication & $x$ & . & Non-jonizing Radiation . & & $\mathbf{x}$ & Entergency Controls & $\mathrm{x}$ & \\
\hline Lasers & $\therefore$ & $x$ & Aerial LiAs & & $\mathbf{x}$ & Airbome Pathogens & & $\mathbf{x}$ \\
\hline \multirow[t]{2}{*}{ Electromagnetic Rad } & & $x$ & Flammable/Combustible Materials & $x$ & & Permits Required & $x$ & \\
\hline & & & & & & Training & $x$ & \\
\hline $\begin{array}{l}\text { If additional hazar } \\
\text { independent } S \& H\end{array}$ & overed & ing & $\begin{array}{l}\text { conduct of this activity, work shatl } \\
\text { work ean reoume. }\end{array}$ & & & is are controlled APp & ) of & \\
\hline
\end{tabular}


HNF-3210 Rev. O

ACTIVTY HAZARD ANAIYSIS

WASTE MANACEMENT FEDERAI SERVICES, INC.

HANFORD SITE

\section{JOB HAZARD CONTROIS CHECKIXST}

For each item checked "yes" on Hazards Analysis, complete a box below outlining the primary control measures to mitigate/control beaith \& safety hazards. When an item is a non-hazard program or procedural requirement, then provide applicable information.

ELECTRICAL: Power lines are within 20 ft of the sample location (numbers 5 and 6 ). The electrical utilities will be contacted and power turned off if required.

MANUAX IXFTING: Use proper lifting techniques (bend knees, straight back, firm grip on load). Use buddy system for heavy/oulk/awkward loads.

PNCFPOINTS/GUARDING: Wear sturdy leather work gloves when handling equipment and tools. Assure all guards are in place and functional. Be watchful of moving parts and other potential pinch points.

WALKING SURFACES: Wear substantial footwear with lugged or other non-slip sole. Be careful of equipment on-the ground. Keep work area picked up.

EXCAVATION: An approved Excavation Permit, with appropriate signatures, is needed prior to drilling operations.

OVERFEAD HAZARDS: Level D PPE is required. Be aware of orerhead operations.

FALLING OBJECTS: Level D PPE is required. Conduct weekly and monthly Checklist for drill unitpump setting rig.

SANITATION: Have wash water, soap and towels available. Know the location of the nearest portable toilet or restroom.

HAZARD COMMUNICATION: OSHA 1910.1200 hazard communication will be posted at the 600 Area Pipeyard for employees.

NOISE: Wear hearing protection when drill unit, work-over unit, support equipment is operating. Post work ares 'Hearing Protection Required."

DUST: During dust storms that create a hazardous work environment, work will STOP.

TEMPERATURE EXTREMIES: Wear clothing appropriate for prevailing weather conditions. Know the symptoms of heat/cold stress and monitor each other for symptoms. Have plenty of drinking water available during hot weather and encourage frequent water consumption. Have shaded/warming areas available for rest breaks, depending on conditions.

CHEMICALS: Develop and maintain an MSDS file for ready reference of all chemicals and chemical products used on the job (ie; oils, lubes and fluids). Secondary containers will be labeled appropriately.

BIOLOGYCALHAZARDS: Be watchful for poisonous reptiles/insects around work area, particularly beneath equipment that has rested on the ground over night and in shaded areas beneath shrubs. Watch where you reachl If encountered, do not altempt to handle reptiles or insects. Contact BHI animal control at 373-1383/531-0719.

RADIOLOGICAL FAZARDS: Rad Con will evaluate data to determine necessary protocol. A Radiation WorkPermit will be developed if contamination levels are reached beyond set limits.

DRWIING: Be aware of rotating pipe (stand clear) it can grab. Be aware of pinch points.

SITE CONTROL: Demarcate work area by use of traffic cones and/or a rope boundary. Post work area for PPE requirements. Keep unauthorized personnel away from operating equipment. A map is attached for access/egress.

FLAMMAABLE/COMBUSTHBLE MATERTALS: Store in approprate and labeled containers. 
SHARP OBJECTS: Be aware of shapp objects and wear gloves.

GUARDING: All guards mușt be in place and secure.

HAND TOOLS: Inspect tools before use. Replace defective/worn tools. Use correct tool for the task. Do not attempt to modify tools.

FIRST AM: Supervisor and at least one ađditional crew to be first Aid/CPR trained. First aid kit shall be available on job. See Page \#4 for emergency phone numbers.

EMERGENCY CONTROLS: Emergency Control contacts are Dan Edwards (372-2429) or Marty Gardiner (372-8029). A radio and/or cellular phone will be onsite and operational at all times.

PERMIIS: RWP, as determined by Radcon. Excavation permit, Biological and Cultural reviews.

TRAINING: (1) Operators to be qualified to operate associated equipment, i.e., SIMCO auger dirll, sampling equipment, and support equipment. (2) Crew to read and acknowledge the AHA governing activity. (3) Hearing conservation and baseline audiogram. and (4). Conduct and docuritent Pre-Job Briefing prior to start of activity and daily Safety Briefing. 
ACTVITY HAZARD ANALYSIS

YASTE MANAGEMENT FEDERAL SERVICES, INC.

HANFORD SITE

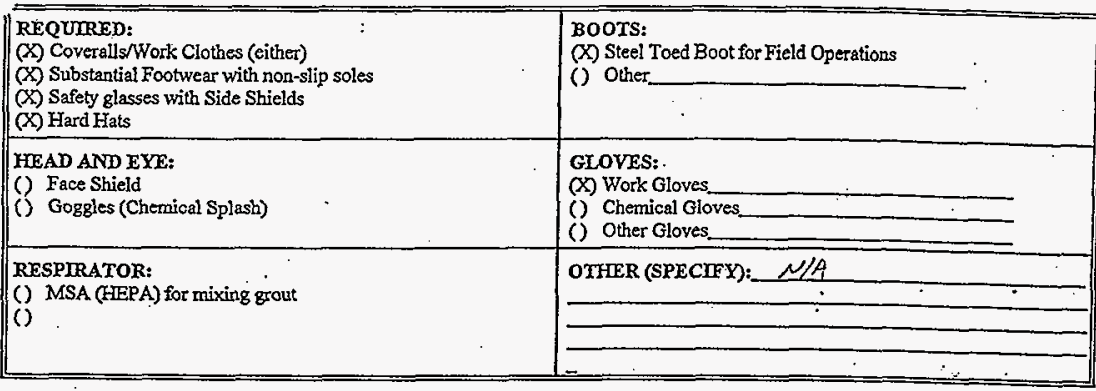

\begin{tabular}{|c|c|c|c|}
\hline EMERGENCY CONTACTS · & & $\begin{array}{l}\text { OFHCE } \\
\text { PHONE }\end{array}$ & $\begin{array}{l}\text { CELLULAR } \\
\text { PHONE }\end{array}$ \\
\hline $\begin{array}{l}\text { 24-Hour All Employee Line - } \\
\text { Fire/Patrol/Ambulance }\end{array}$ & $\begin{array}{l}\text { Land Line: } \\
\text { Cellular Phone: }\end{array}$ & $\begin{array}{l}811 \\
373-3800 \\
\end{array}$ & . \\
\hline Occurrence Reporting & & $376-2900$ & : \\
\hline safety Representative & Mike Madison & $373-3722$ & \\
\hline Field Superintendent & Bob Jones & $373-2048$ & . \\
\hline Task Lead & Field Superintendent & $372-8045$ & \\
\hline Project Manager & Marty Gardner & $372-8029$ & \\
\hline \multicolumn{4}{|l|}{ 199-B3-2 Site Cellular Phone } \\
\hline 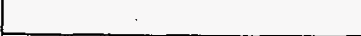 & & & \\
\hline Radio & R\&R & & \\
\hline MEDICAX EMERGENCY: & . & & . \\
\hline First Aid Stations/Hospital & & & . \\
\hline 100-N Area & Bldg. $1115 \mathrm{~N}$ & $373-1695$ & \\
\hline 200 East & Bldg. 2719EA & $373-2314$ & \\
\hline 200 West & BIdg. 2719WB & $373-2714$ & . \\
\hline 300 Area & Bldg. 3719A & $376-3315$ & \\
\hline HEYF & 3080 Geo. Wash. Way & $376-6981$ & \\
\hline Federal Building & Medical Services & $376-7022$ & . \\
\hline Kadelec Medical Center & 888 Swift Blvd. & $946-4511$ & \\
\hline
\end{tabular}


ACTIVTTY HAZARD ANALXSIS

VYASTE MANAGEMENT FEDERAL SERVICES, INC

HANFORD SITE

\section{ACTIVITY HAZARD ANALYSIS ACKNOWLEDGMENT}

I have read, understand, and agree to abide by the provisions detailed in this Activity Hazard Analysis. I understand that failure to comply with these provisions may lead to disciplinary action and my removal from this job activity.

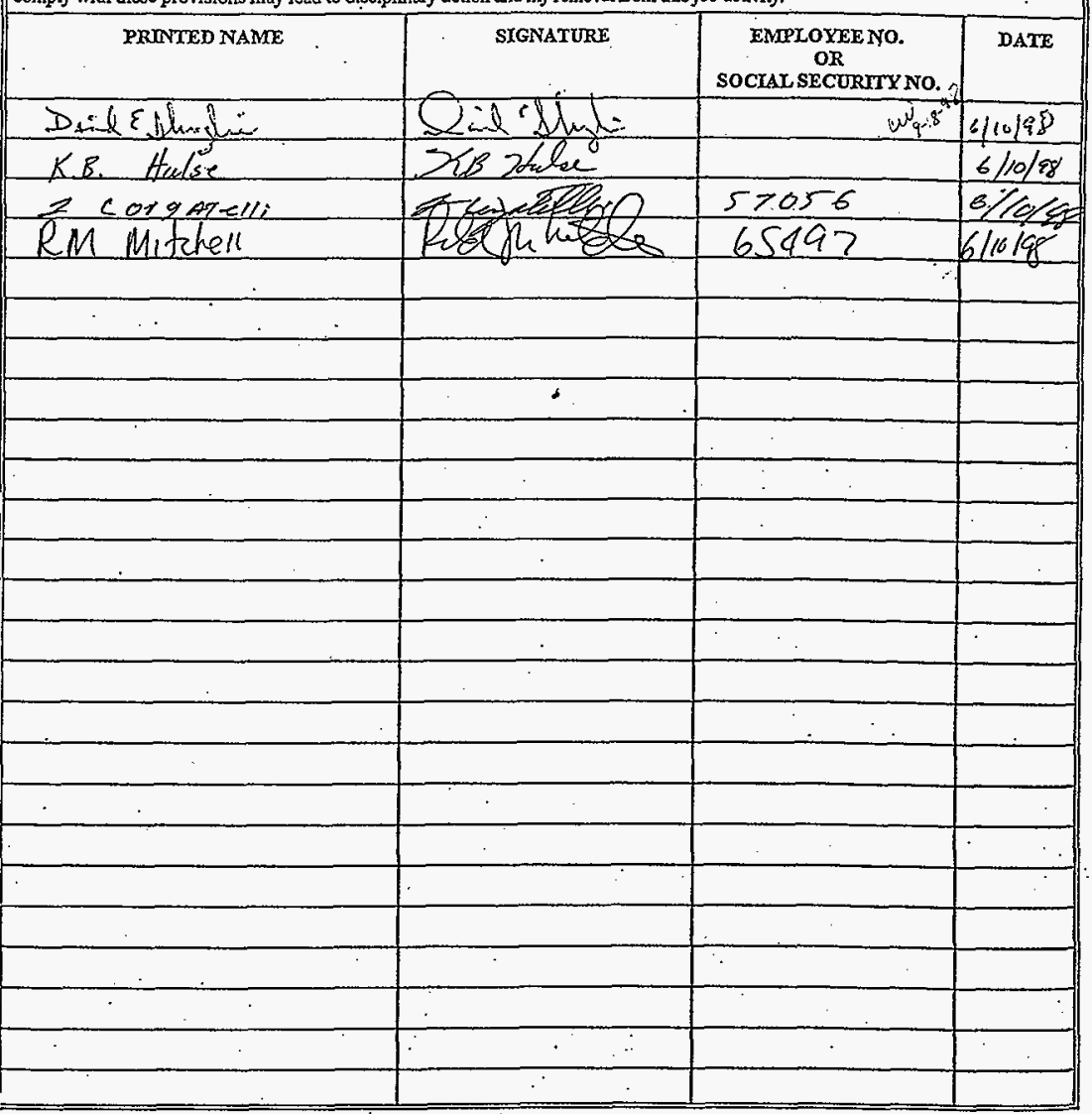


This page intentionally left blank. 
Rev, 0

Attachment B.

Excavation Permit. 
Rev. 0

This page intentionally left blank. 


\begin{tabular}{|c|c|}
\hline \multicolumn{2}{|c|}{ HANFORD SITE EXCAVATION PERMIT } \\
\hline \multicolumn{2}{|c|}{\begin{tabular}{|l|l|l|} 
7. Work Packago No. & 2. W.o.fFrojoct No. \\
W519 & $772029 / 23005001$ & 3. Location of Excavation \\
200 EAST AND ADJACENT AREA @ EAST SIDE, 12N 26E sec 1
\end{tabular}} \\
\hline 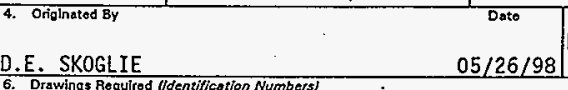 & $\begin{array}{l}\text { 5. Engineoring Change Notico }\{E C M \\
N / A\end{array}$ \\
\hline \multicolumn{2}{|c|}{ 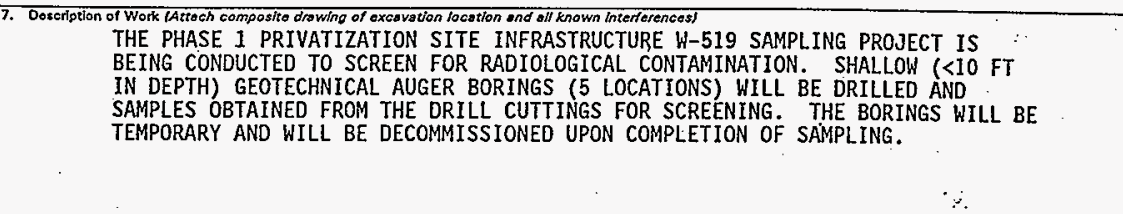 } \\
\hline \multicolumn{2}{|c|}{$\begin{array}{l}\text { RADIOLOGICAL CONTROL TECHNICIAN(S) WILL BE PRESENT CONTINOUSLY TO MONITOR } \\
\text { THE AUGER CUTYINGS WHENEVER A CHANGE OCCURS IN THE SOIL, i.e., COLOR, } \\
\text { MOISTURE CONTENT, EtC., OR AT APPROXIMATELY } 2 \text { FT INTERVALS. } \\
\text { A JOB SPECIFIC ACTIVITY ANALYSIS (AHA) WILL BE PREPARED AND REVIEWED BY } \\
\text { PERSONNEL CONDUCTING THIS WORKSCOPE. A PRE-JOB SAFETY MEETING WILL BE HELD } \\
\text { PRIOR TO THE START OF SAMPLING ACTIVITIES. }\end{array}$} \\
\hline \multicolumn{2}{|c|}{$\begin{array}{l}\text { 9. List Facilities, Sonvices, ond Utilitios Affoeted by Exeavation } \\
\text { ELECTRICAL UTILITIES WILL BE EFFECTED AT SAMPLE LOCATION 5. THE OVERHEAD } \\
\text { POWER LINE. WILL BE SHUT DOWN FOR AUGERING OPERATIONS IF REQUIRED. }\end{array}$} \\
\hline \multicolumn{2}{|c|}{ APPROVALS } \\
\hline 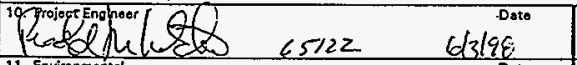 & $\begin{array}{l}\text { 18. Traffic Enginineer } \\
N / A\end{array}$ \\
\hline $\begin{array}{l}\text { 11. Environmental } \\
\text { Phil Milles Per attached fax. }\end{array}$ & $\begin{array}{l}\text { 19. Track Mointenanseo } \\
\text { N/A }\end{array}$ \\
\hline $\begin{array}{l}\text { 12. Rodiological control Pato } \\
\text { DAVE PhepPS } 34749\end{array}$ & $\begin{array}{l}\text { 20. 600 Aros Landlord Per attached fay } \\
\text { R.R. Knight GeCS4 }\end{array}$ \\
\hline $\begin{array}{l}\text { 13. Steam-ESPC } \\
N / A\end{array}$ & $\begin{array}{l}\text { 2i. Saleguarde and Socurity } \\
N / A\end{array}$ \\
\hline M.A. Helle Siriafiached FAY & $\begin{array}{l}\text { 22. Land Uso pranning Per attachect FAx } \\
\text { Boyd Hathauny c7540 }\end{array}$ \\
\hline $\begin{array}{l}\text { 15. Water Utilitios per a Hachuol Fox } \\
\text { P.E.STAnlEy } 39103\end{array}$ & $N / A$ \\
\hline 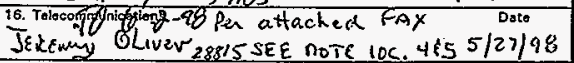 & 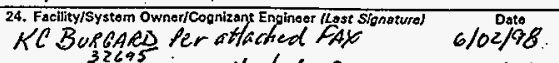 \\
\hline $\begin{array}{l}\text { 17. Processs Sowor-300 Aros } \\
\text { N/A }\end{array}$ & I. A. Voogd per altacherl bax \\
\hline
\end{tabular}

$531 \sim 3100$

CALL 1-800-424-5555, 2 TO 10 WORKING DAYS PRIOR TO DIGGING CAMILE 5/27/48 3 Locales 8:40 InEET TO ShOW SITES 
HNF-3210 Rev. 0

$08 / 01 / 98 \quad 15: 55$ Z373 5030 —

Hanford Site Wido Categorieal Exuluyion Serenring form

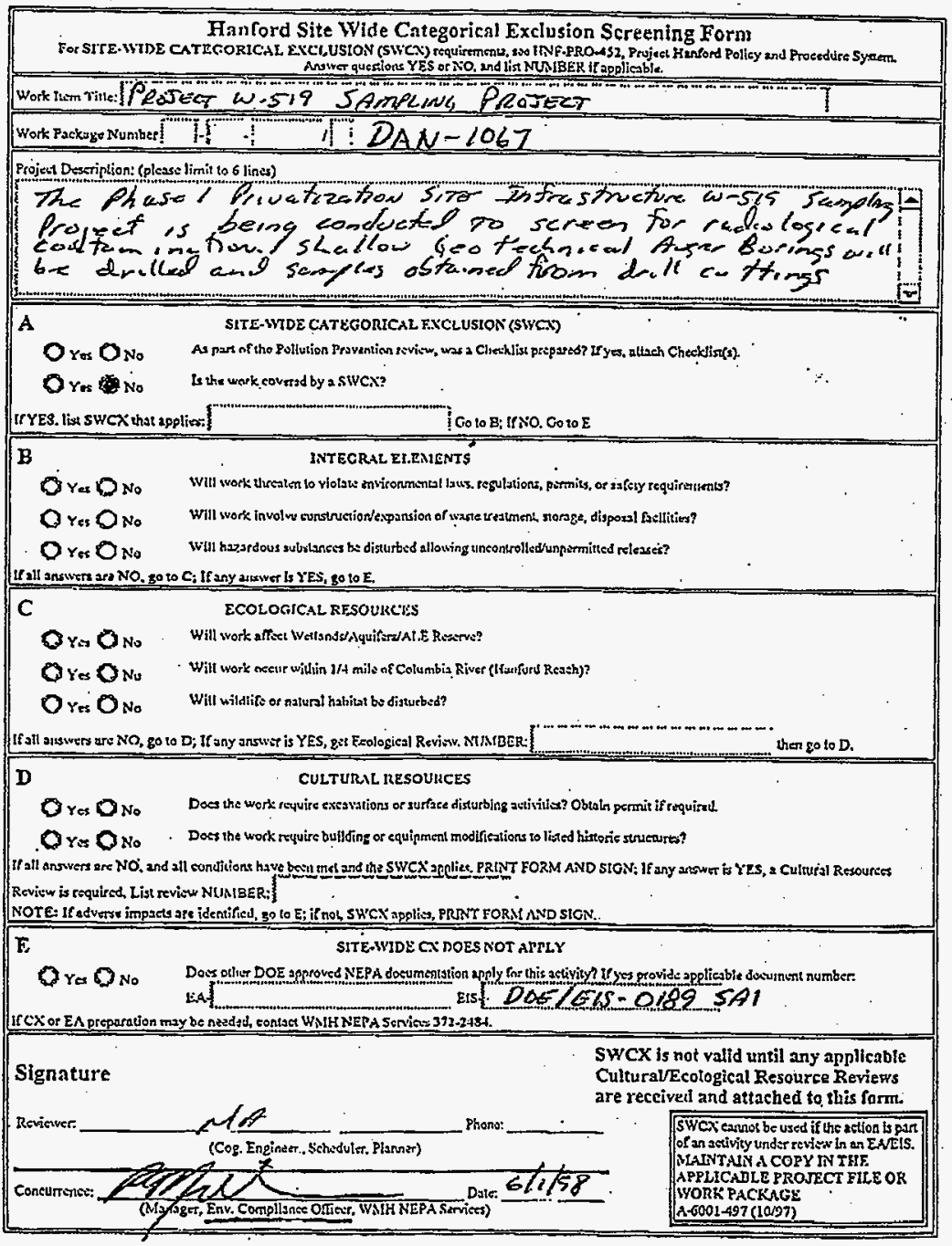




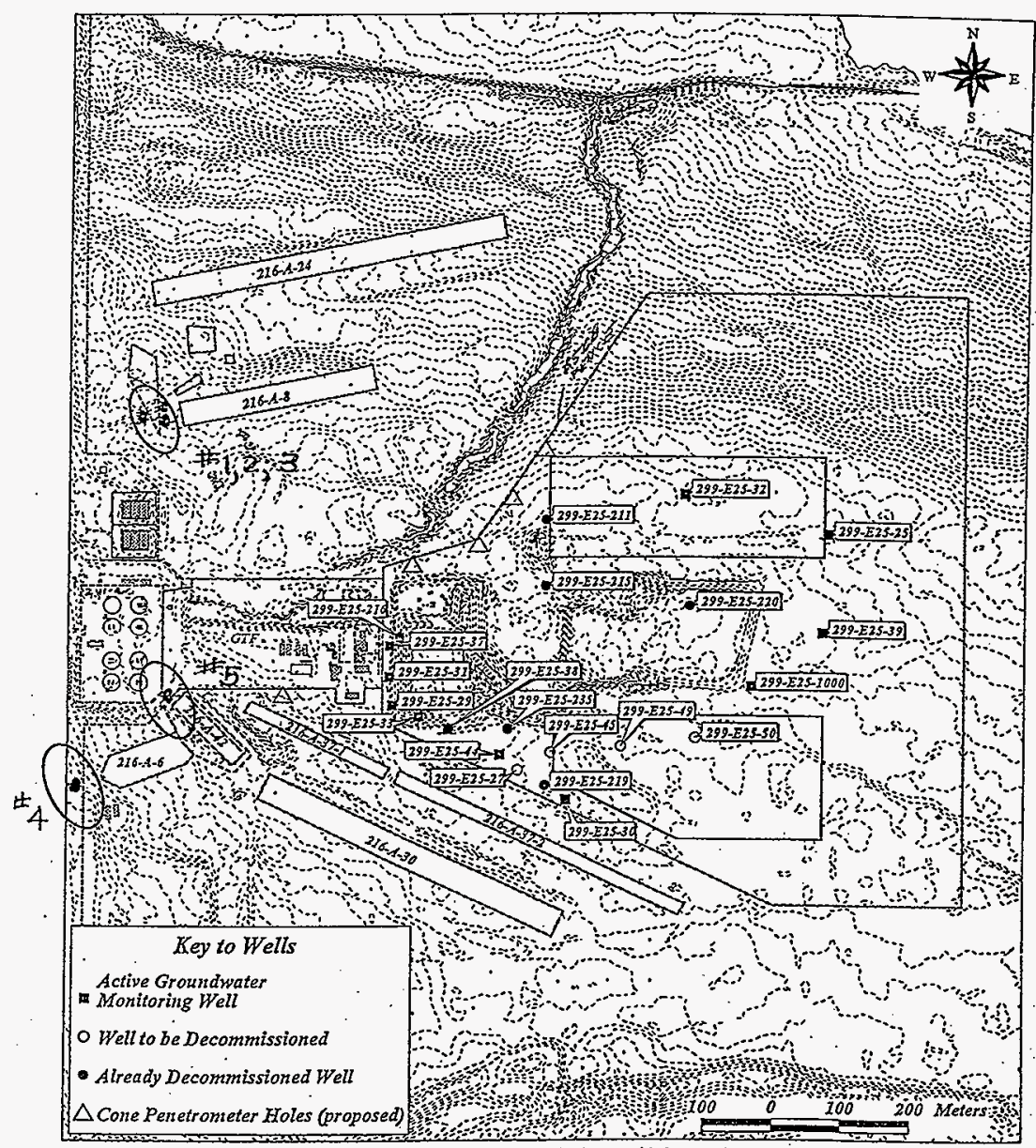

Figure A1-1. Locations of Existing Deep Boreholes and Planned Cone Penetrometer . 5/26/99 Holes at the TWRS Phase I Demonstration Site NOTE: Sites Supporting ussig are Marked with (0) 
This page intentionally left blank.

B-4 
Rev. 0

Attachment $\mathrm{C}$.

Biological and Cultural Reviews. 
Rev. 0

This page intentionally left blank. 


\section{Pacific Northwest National Laboratory}

Operated by Battelle for the U.S. Department of Energy

May 26, 1998

No Known Historic Properties

Mr. D. E. Skoglie

Waste Management Federal N. W.

P. O. Box $650 / \mathrm{H} 1-12$

Richland, WA $99352-0650$

Dear Mr. Skoglie:

CULTURAL RESOURCES REVIEW OF THE W-519 SAMPLING PROJECT. HCRC \#98-200-059.

In response to your request received May 22, 1998, staff of the Hanford Cultural Resources Laboratory (HCRL) conducted a cultural resources review of the subject project, located in the 200 East and 600 Areas of the Hanford Site. According to the intormation that you supplied, the project will entail drilling 5 geotechnical auger borings in order to test for radiological contamination adjacent to pipelines. The borings will be less than 20 feet in depth and approximately 8 inches in diameter. No site preparation is needed prior to drilling with the chain auger. The sampling locations will be in graveled orspreviously excavated areas.

Our literature and records review shows that the borings will be located in industrial areas of the 200 East and 600 Areas in ground that has been disturbed by previous Hanford Site construction activities. It is unlikely that any intact archaeological materials will be affected by the proposed project. Survey of the project area and monitoring of the excavations by an archaeologist are not necessary.

It is the finding of the HCRL staff that there are no known cultural resources or historic properties within the proposed project area. The workers, however, must be directed to watch for cultural materials (e.g., bones, artifacts) during all work activities. If any are encountered, work in the vicinity of the discovery must stop uritil an HCRL archaeologist has been notified, assessed the significance of the find, and, if necessary, arranged for mitigation of the impacts to the find. The HCFL must be notified if any changes to project location or scope are anticipated. This is a Class III case, defined as a project which involves new construction in a disturbed, low-sensitivity area.

Copies of this letter will be sent to D. W. Lloyd, DOE, Richland Operations Office, as official documentation. If you have any questions, please call me at 376-8107. Please use the HCRC\# above for any future correspondence concerning this project.

Very truly yours,<smiles>CCCCCC1CCCC(CCCC)C1</smiles>

N. A. Cadoret

Technical Specialist

Cultural Resources Project

Concurrence:

D. C. Stapp, Profe Manager Cultural Resources Project

cc: D. W. Lloyd, RL (2)

G. D. Cummins

R. J. Swan

File/LB

902 Battelle Boulevard — P.0. Box 999 × Richland, WA 99352 
HNF-3210 Rev. 0

Pacific Northwest National Laboratory

Operated by Battelle for the U.S. Department of Energy

May 26, 1998

$376-5345$

Mr. David Skoglie

Waste Management Northwest

P. O. Box 650, MSIN H1-12

Richland, WA 99352

Dear Mr. Skoglie:

BIOLOGICAL REVIEW FOR THE W-519 SAMPLING PROJECT, 200 East Area, \#98200-059

Project Description:

- Drill 5 shallow $\left(<20^{\prime}\right.$ in depth) geotechnical auger borings in graveled or previously excavated areas.

Survey Objectives:

- To determine the occurrence in the project area of plant and animal species protected under the Endangered Species Act (ESA), candidates for such protection, and species listed as threatened, endangered, candidate, sensitive, or monitor by the state of Washington, and species protected under the Migratory Bird Treaty Act,

- To evaluate the potential impacts of disturbance on priority habitats and protected plant and animal species identified in the survey.

\section{Survey Methods:}

- Pedestrian and ocular reconnaissance of the sites proposed for the 5 geotechnical auger borings was conducted by M. Sackschewsky, C. Duberstein, and J. Becker May 26, 1998.

- Priority habitats and species of concern are documented as such in the following: Washington Department of Fish and Wildlife $(1996,1998)$, Washington State Department of Natural Resources (1997), and for migratory birds, U.S. Fish and Wildlife Service (1985). Lists of animal and plant species considered Endangered, Threatened, Proposed, or Candidate by the USFWS are maintained at 50 CFR 17.11 and 50 CFR 17.12.

\section{Survey Results:}

- All of the sites proposed for the 5 geotechnical auger borings have been previously disturbed and are occupied by weedy vegetation consisting largely of Russian thistle (Salsola kali).

- No avian use of the sites proposed for the 5 geotechnical auger borings was observed. 
Mr. David Skoglie

98-200-059

Page 2 of 2

\section{Conclusions and Recommendations:}

- No plant and animal species protected under the ESA, candidates for such protection, or species listed by the Washington state government as threatened or endangered were observed in the vicinity of the sites proposed for the 5 geotechnical auger borings.

- No adverse impacts to species, habitats, or other biological resources are expected to result from the proposed action.

- This Ecological Compliance Review is valid until 15 April 1999.

Sincerely,

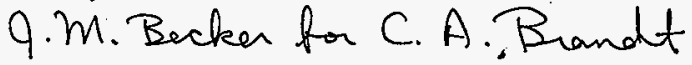

CA Brandt, Ph.D.

Project Manager

Ecological Compliance Assessment

CAB:jmb

\section{REFERENCES}

Bonham, Charles D. 1989. Measurements for Terrestrial Vegetation, John Wiley \& Sons, Inc. pp. 127-128.

U. S. Fish and Wildlife Service. 1985. Revised List of Migratory Birds; Final Rule. 50 FR 13708 (April 5, 1985).

Washington Department of Fish and Wildlife. 1994. Species of Special Concern in Washington. (April 1994).

Washington Department of Fish and Wildlife. 1996. Priority Habitats and Species List. (January 1996).

Washington Department of Natural Resources. 1997. Endangered, Threatened \& Sensitive Vascular Plants of Washington (August 1997). 
HNF-3210 Rev. 0

This page intentionally left blank. 
HNF-3210 Rev. 0

Attachment D.

Soil Evaluation.

D-i 
HNF-3210 Rev. 0

This page intentionally left blank. 
HNF-3210 Rev. 0

DON'T SAY IT -... Write It!

To: Dave Skoglie

$\mathrm{H} 1-12$
DATE: May 26, 1998

FROM: Scott E. Myers

H1-12

Telephone: $372-8033$

SUBJECT: Waste Management Support for TWRS Infrastructure W519

Characterization Project

In general, soil removed from a contaminated area for investigative purposes can be returned to that area. This doesn't mean that soif from an adjacent area can be dumped. It means that soil removed from a specific area for sampling, etc., can be returned to that specific area, given that no increased potential for site contamination or personnel exposure is realized. Piease see the attached letter "Management of Contaminated Soil from Nonremediation Activities at the Hanford Site" for more complete information.

Soil removed from the investigation points for this project may be controlled during sampling activities and then returned to the boreholes. Any plastic, wipes, etc., which are generated during this work scope which can't be released for disposal must be retained and packaged as radioactive waste.

For further information concerning packaging or management of this waste, please contact me.<smiles>CCCCCCCCCCCCCCCCCCC</smiles> 


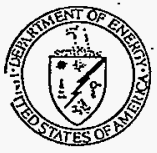

\section{Department of Energy}

Richland Operations Office

P.O. Box 550

Richland, Washington 99352

Jul $\mathrm{O}_{2}$

96-EAP-186

Mr. Michae 1 Bussell, Director

Office of Waste and Chemical Management

U.S. Environmental Protection Agency

Region 10

1200 Sixth Avenue

Seattle, Washington 98101

Mr. Michael A. Wilson

Program Manager

Nuciear Wasțe Program

State of Washington

Department of Ecology.

P.0. Box 47600

0lympia, Washington $98504-7600$

Dear Messrs. Bussell and Wilson:

MANAGEMENT OF CONTAMINATED SOIL FROM NONREMEDIATION ACTIVITIES AT THE HANFORD SITE

- In a letter from the State of Washington Department of Ecology (Ecology) and the U.S. Environmental Protection Agency (EPA) entitled "Proposed Site Policy. for Management of Contaminated Soi1," dated September 14, 1994, to the U.S. Department of Energy, Richland Operations Office (RL) it was proposed. that appropriate staff from RL and the above agencies work together to reach agreement on substantive elements of a contaminated soils management policy. Staff from these agencies have been meeting with representatives of $R L$ and $\mathrm{RL}$. contractors to resolve contaminated soil issues and reach agreement on a practical, workable policy. Ecology was designated the Lead Regulatory Agency.

The policy described in this letter is the result of that joint effort and will be implemented immediately on the Hanford Site. Your formal response and agreement on the policy is requested.

Purpose: The purpose of this policy is to define a consistent approach at the Hanford Site for managing contaminated soil encountered during excavation activities.

The contaminated soil poijcy is relatively simple. In most cases, it is expected that contaminated soil encountered during excavation activities will be returned to the site of the original excavation at the conclusion of the activity. While awaiting return to the ground, contaminated soil will be managed in a manner to prevent the spread of contamination. Management of contaminated soil wil] be conducted so as to be protective of human health and the environment. 
HNF-3210 Rev. O

- Messrs. Bussell and Wilson 96-EAP-186

$-2-$

Scope: The premise for this policy is that, as representatives from EPA and Ecology have agreed, excavation activities are considered to be normal earth. moving and grading activities which are not considered "placement, "are not considered waste treatment, storage, or disposal, do not trigger requirements found in the Land Disposal Restrictions, and are not subject to any generator requirements. For environmental remediation (ER) activities, the proper disposition of contaminated soil is generally described in the appropriate decision documents. However, for excavation activities not associated with . remediation where final cleanup is not the objective, such as.excavation for : routine maintenance, common trenching for pipeline installation, or excavation for building foundation construction, there has been no sitewide poilcy for proper disposition of contaminated soil. This policy applies to soils displaced during nonremediation excavation activities.

Contaminated soil will not be returied to its original excavation if such action would create As Low As Reasonably Achievabie (ALARA) concerns. Management of contaminated soil must avoid significant adverse impacts to exposure pathways to humans and the environment. For example, creating significant surface contamination at a site that was previously uncontaminated would have an adverse impact on exposure pathways and would preclude return of the soil to ground. Management of contaminated soil will not be allowed to create unacceptable exposure of radiological or hazardous chemical constituents to workers, the public, or environmental receptors.

Potential occupational exposures to hazardous substances and radiological substances during excavation activities are minimized by adhering to requirements in Hanford Site industrial safety programs and the Hanford site Radiological .Control Manual (HSRCM-1). Industrial safety programs prescribe the use of appropriate field monitoring instruments when there is a reasonable possibility of exposing an employee to hazardous substances at concentrations. or levels in excess of published occupational exposure standards. . As discussed in HSRCM-1, Radiation Work Permits are used to control the entry into radiation and contamination areas. The details of monitoring and surveys for radiation, contamination, and airborne radioactive materials are specified in these work permits.

As part of the contaminated soil policy, it is important for the Hanford site $:$ contractor conducting excavation activities to communicate excavation and soil management. plans with the Hanford Site remediation contractor. Management of contaminated soil cannot be al lowed to adversely impact current or future remediation of an operable unit. Excavations and management of contaminated soil will be coordinated with the environmental remediation contractor to avoid adverse impacts to remediation activities. When soil contamination is discovered during an excavation.activity, the contractor responsible for the excavation will be responsibie for documenting this contamination in the Waste Information Data System. Information in this database will be used by the remediation contractor to help plan the future remediation of the site. 
HNF-3210 Rev. 0

Messrs. Bussell and Wilson

The contaminated soil policy does not apply to current spills or unpermitted discharges of dangerous wastes or hazardous substances. In these cases, the source of the spili needs to be identified, the unpermitted discharge stopped, and the spill site remediated, as necessary, per the requirements of the Washington Administrative Code, Section 173-303-145(3). Soil cleaned up during remediation of an active spill site cannot be returned to ground.

Contaminated soil that cannot be returned to its excavation site will be considered waste, will be properiy designated, and will be managed in accordance with all applicable regulations. For those waste soils that are designated as dangerous waste due to the contained-in policy, RL may elect to request a determination from Ecology that the contaminated soil no longer. contains dangerous waste when the concentrations of dangerous waste constituents in the soil are below specific health-based levels. Such "contained-in determinations" will be requested on a case-by-case basis. Along these lines, RL encourages Ecology to adopt the Hazardous Waste Identification Rule, with its concentration-based exit levels for certain listed wastes, as soon as possible once the rule is finalized.

In summary, it is expected that most cotitaminated soil displaced during excavation activities will be returned to the ground in the generat vicinity of the original excavation. ALARA concerns may preclude returning excavated soil directly to ground, in which case the contaminated soil would be managed as any other waste generated on the Hanford Site.

Should you have any questions on this matter, please contact Felix Miera of my staff, on (509) 373-7589, or Eric Greager of WHC Environmental Services Division, on (509) 376-3132.

\section{EAP:FRM}

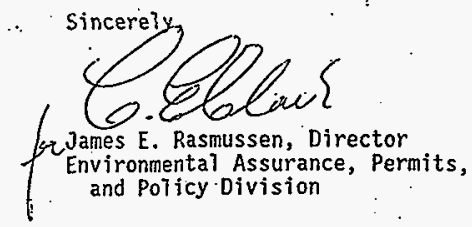

Cc: W. Dixon, HHC

E. Greager, WHC

T. Lazarski, PNNL

R. Jim, YIN

D. Powaukee, NPT

J. WiTkinson, CTUIR 
Attachment E.

Radiological Survey Reports. 
This page intentionally left blank. 


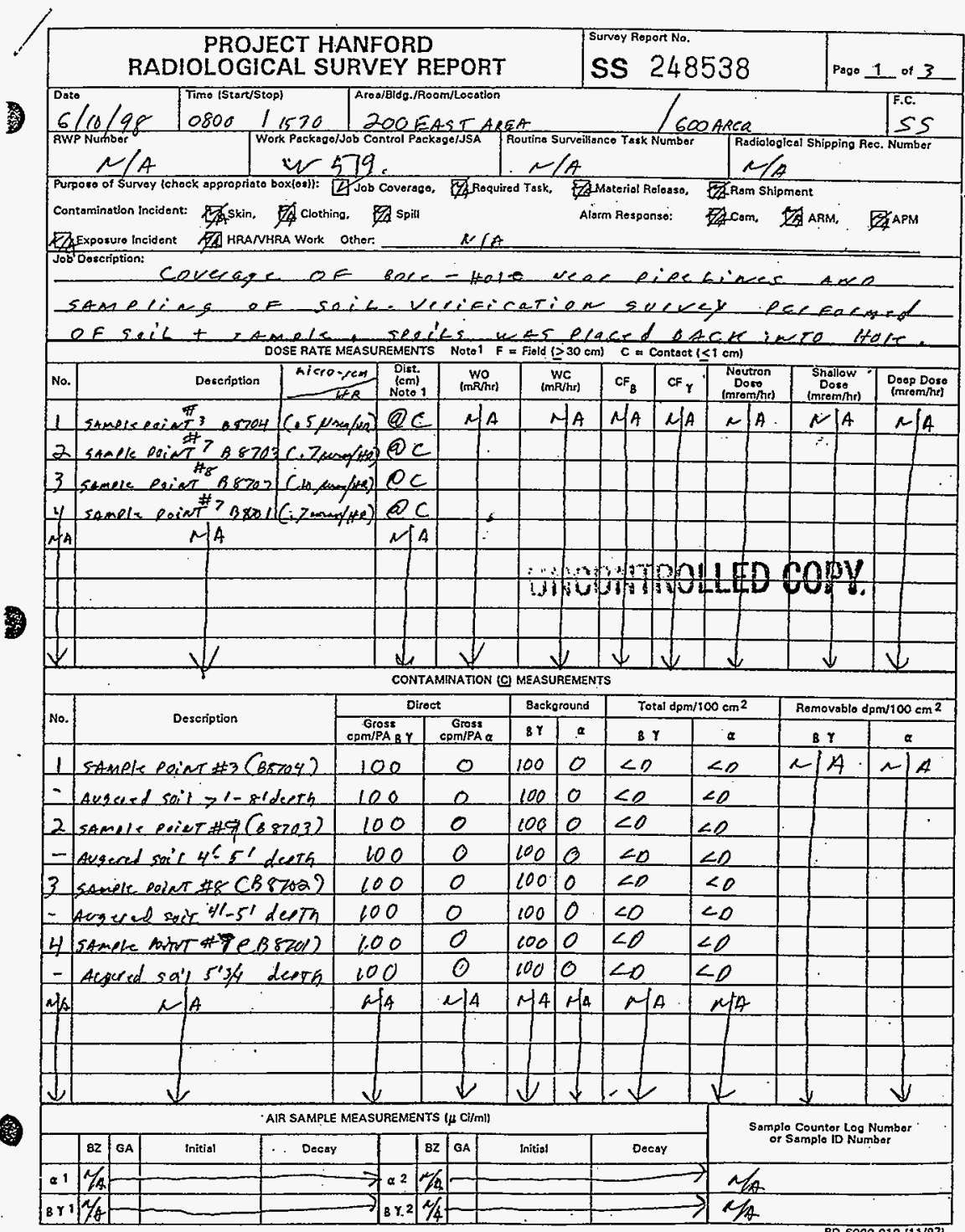


[L6/1 L] 8010-0009-09

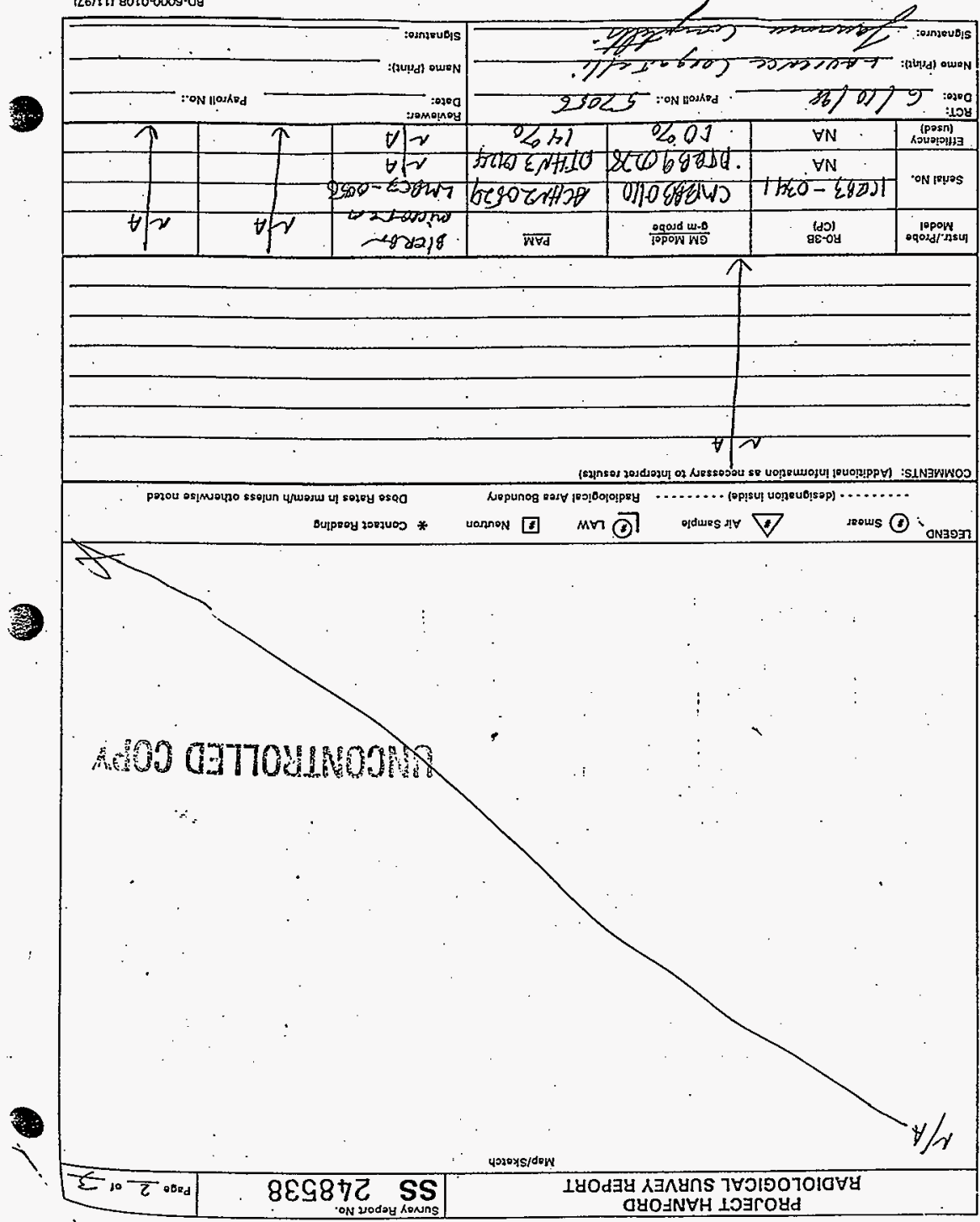




\section{PROJECT HANFORD RADIOLOGICAL SURVEY REPORT}

Survoy foport No.

SS 248543

Pogo 1 of 2

\section{(1)}

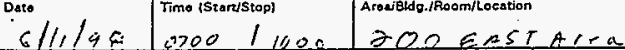

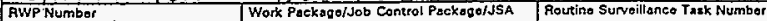

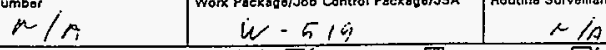

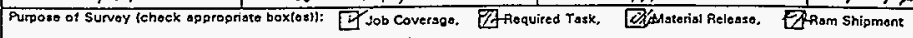

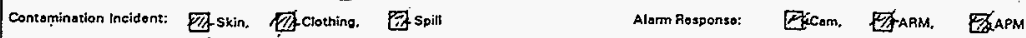

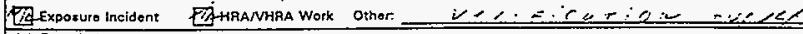

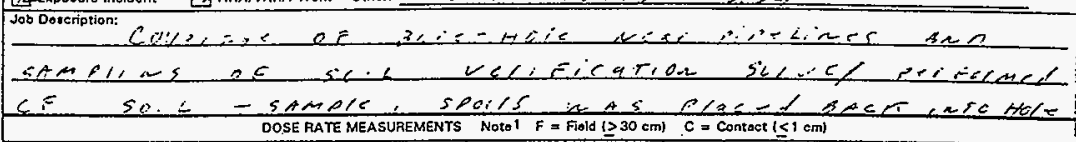

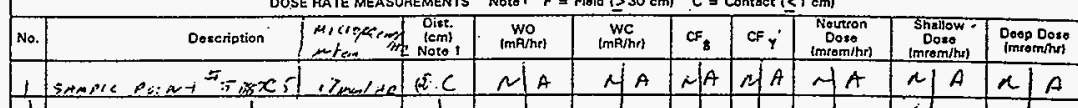

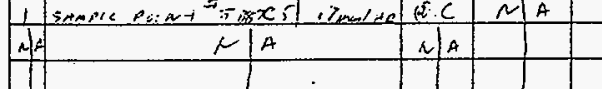
\begin{tabular}{|l|l|l|l|}
\hline & & & \\
\hline 1 & & & \\
\hline 1 & & & \\
\hline 1 & & & \\
\hline 1 & & & \\
\hline 1 & $\sqrt{2}$ & \\
\hline
\end{tabular} \begin{tabular}{l|l|l}
\hline & & \\
\hline & &
\end{tabular}

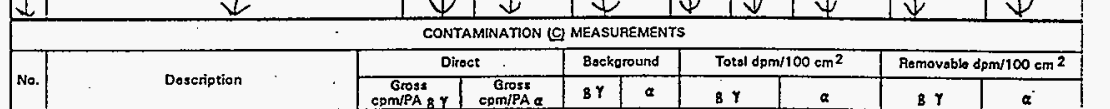

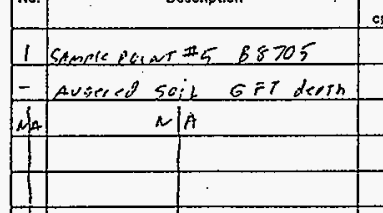
\begin{tabular}{|l|l|l|l|l|l|}
\hline & & $\cdot$ \\
\hline & &
\end{tabular} (1)

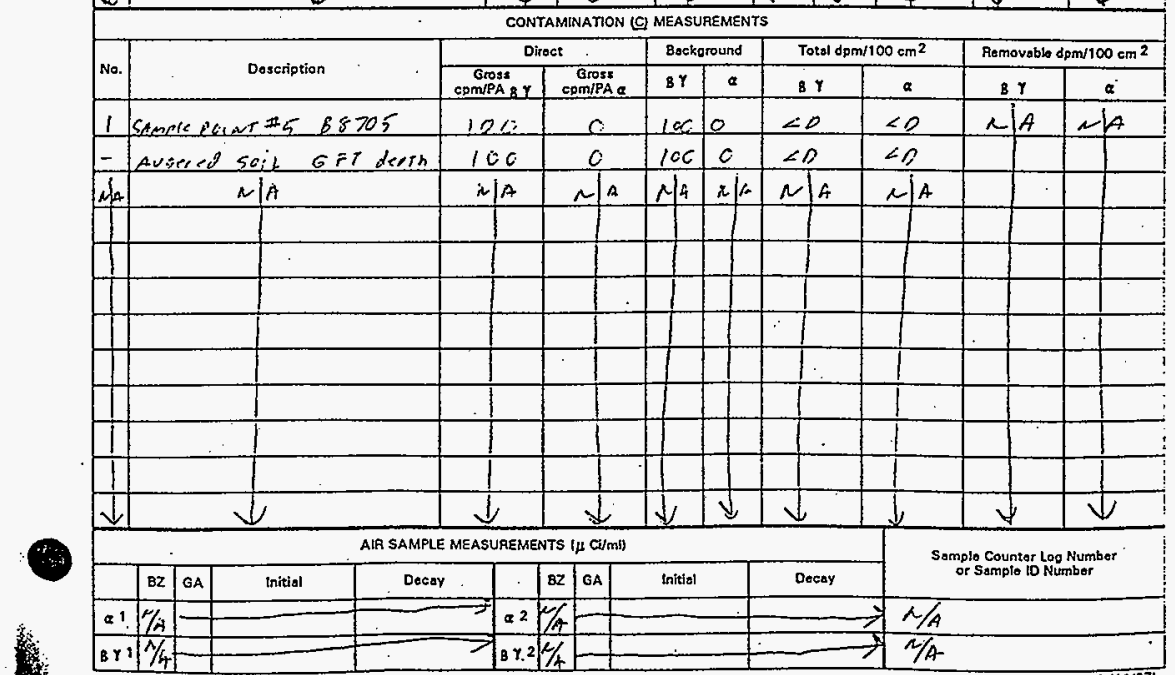


HNF-3210 Rev. O

40б-

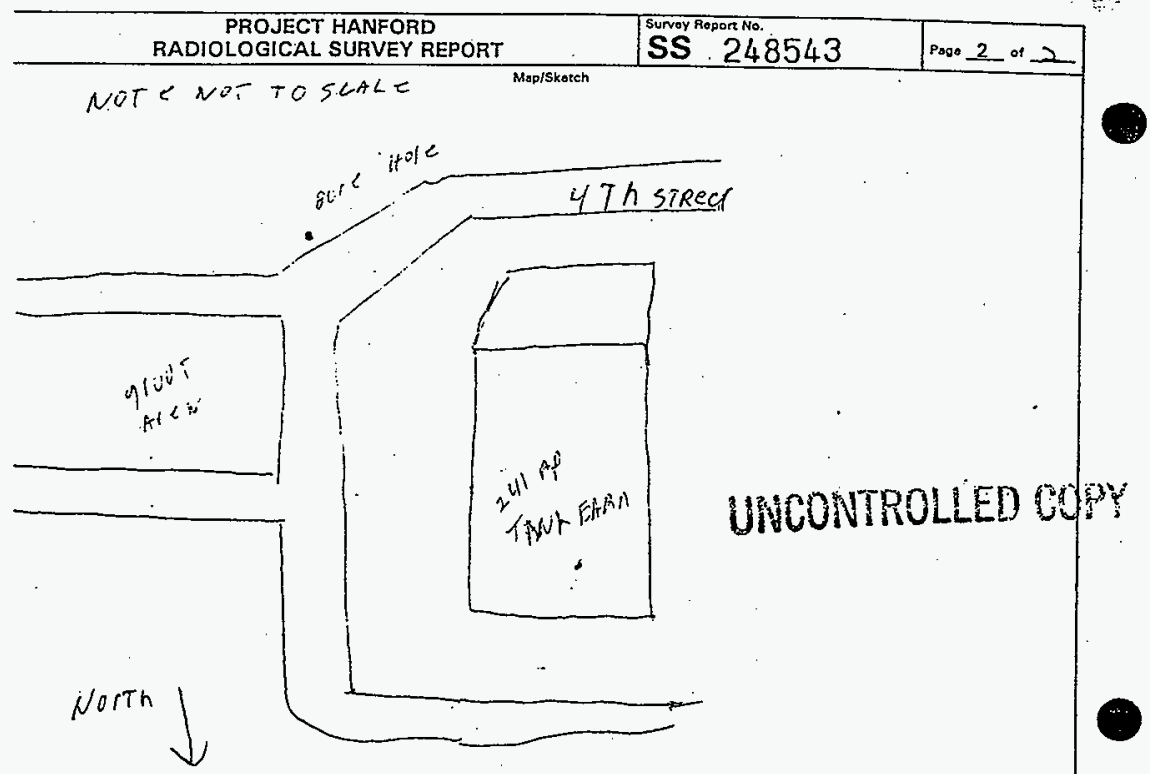

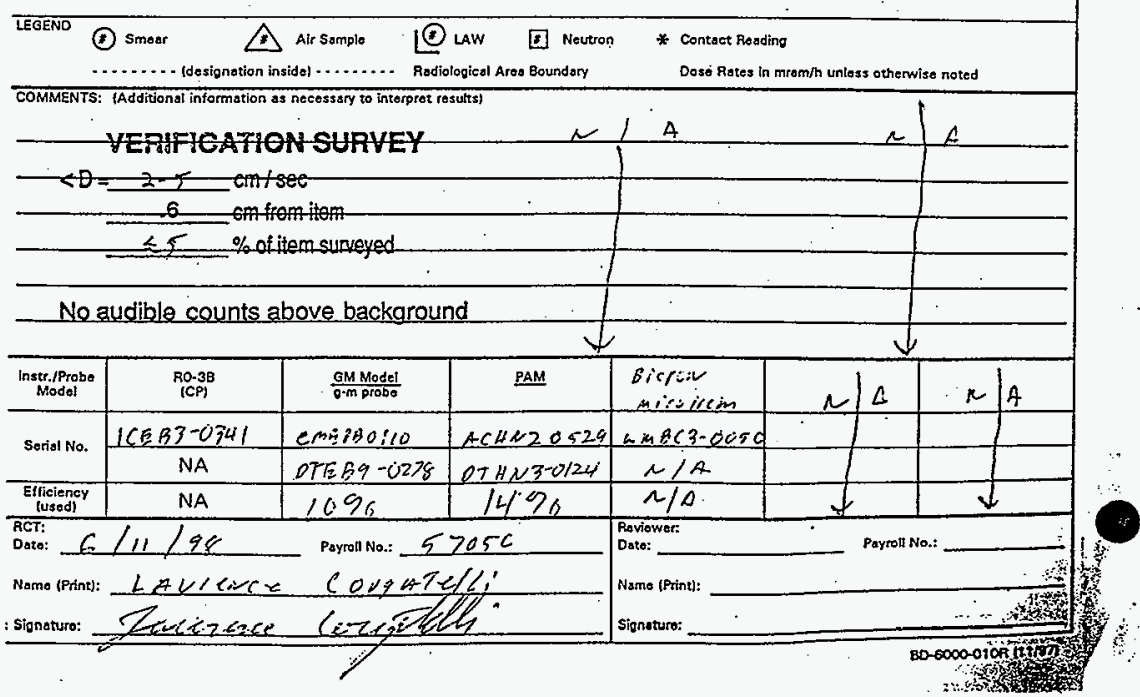


HNF-3210 Rev. 0

Attachment $F$.

Start Card. 
HNF-3210 Rev. 0

This page intentionally left blank. 


\section{Notice of intent to Construct a GEOTECHNICAL SOIL BORING

Alitition

ICOLOG

This form must be received by the Department of Ecology 72 hours prior to construction of soll boring. Complote this form end mail to Department of Ecology, Water Resources Frogrem, Well Dniling Unit, P.O. Box 47600,

Olympla, WA 985047600. Instructions for filing out this form sro printed on the back.

1. Property Owner U.S. Department of Energy

Phone No.

$509 \quad 372-9176$

Address (include city, state, zip) $825 \mathrm{Jadwin}$ Ave, Richland, WA. 99320

2. Agent (if different from $\# 1$ ) Numatec

Phone No.

$509 \quad 372-2435$

Address (include city, state, zip) 2440 Stevens, H1414A, Richland, WA. 99352

3. Project Name W519 Project; Radiological Contamination Screening

4. Well Location: $1 / 4$ of the $1 / 4$ Section 01 Township $12 \mathrm{~N}$ Rangez6E EWM (circlo one) Address (if known) Well ID H's: B8701; B8702; B8703; B8704; B8765

5. Location of Well(s)

$\square$ Adams County
$\square$ Asotin County
Benton County
$\square$ Chelan County
$\square$ Clallam County
$\square$ Clark County
$\square$ Columbia County
$\square$ Cowlitz County
$\square$ Douglas County
$\square$ Ferry County
$\square$ Franklin County
$\square$ Garfield County
$\square$ Grant County

01-ERO
02-ERO
03-CRO
04-CRO
05-SWR
06-SWR
07-ERO
08-SWR
O9-CRO
10-ERO
$11-E R O$
$11-E R O$
$13-E R O$

$\square$ Grays Harbor County
$\square$ Island County
$\square$ Jefferson County
$\square$ King County
$\square$ Kitsap County
$\square$ Kittitas Counts
$\square$ Klickitat County
$\square$ Lewis County
$\square$ Lincoln County
$\square$ Mason County
$\square$ Okanogan County
$\square$ Pacific County
$\square$ Pead Oreille County

14-SWR
15 -NWR
$16-S W R$
$17-N W R$
$18-N W R$
$19-C R O$
$20-C R O$
$21-S W R$
$22-E R O$
$23-S W R$
$24-C R O$
$25-S W R$
$26-E R O$

$\square$ Pierce County
$\square$ San Juan County:-
$\square$ Skagit County
$\square$ Skamania County
$\square$ Snohomish County
$\square$ Spokane County
$\square$ Stevens County
$\square$ Thurston County
$\square$ Wahkiakum County
$\square$ Walla Walla Coumty
$\square$ Whatcom County
$\square$ Whitman County
$\square$ Yakima County

27-SWR

28-NWR 29-NWR 30.SWR 31-NWR 32-ERO 33-ERO 34SWR 35-SWR 36-ERO 37-NWR 38-ERO 39-CRO 5 7. Approx soil boring construction date

8. Well Driting Co Name, llasto Management_Eederai Srucs, Inc. Phone No $322-9945$

9. Well Driller's Name Dave skoolie

Driller's License No 1580

10. Contractor's L \& I Registration No

11. Please fill out the portion below carefully. The retum address label must contain the name and address of the person submitting this notification. This portion will be validated and retumed to them as proof of . notification. Send the entire form to Department of Ecology, Water Resources Program, Well Drilling Unit, P.O. Box 47600, Olympia, WA $98504-7600$.

This notification number must be provided to your well driller:

Submit by (return address)

Name Martin Gardner

Mailing Address P.O. Box 650/ H1-12

City Richland Stat

Zip 99352

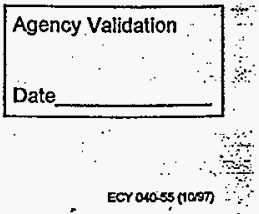


HNF-3210 Rev. 0

This page intentionally left blank.

F-2 
Attachment G.

WSCF Analytical Laboratory Report. 
HNF-3210 Rev. 0

This page intentionally left blank.

G-ii 


\section{WSCF \\ ANALYTICAL LABORATORY REPORT}

for

PROJECT HANFORD MANAGEMENT CONTRACTORS

RICHLAND WA 99352

Attention: RON MTCCHELL T3-30 FX 2-3396

Reportf: 98000843

Report Date: 29-jun-1998

W004

PROJECT HANFORD MANAGEMENT CONTRACTORS 


\section{WSCF}

\section{ANALYTICAL LABORATORY REPORT}

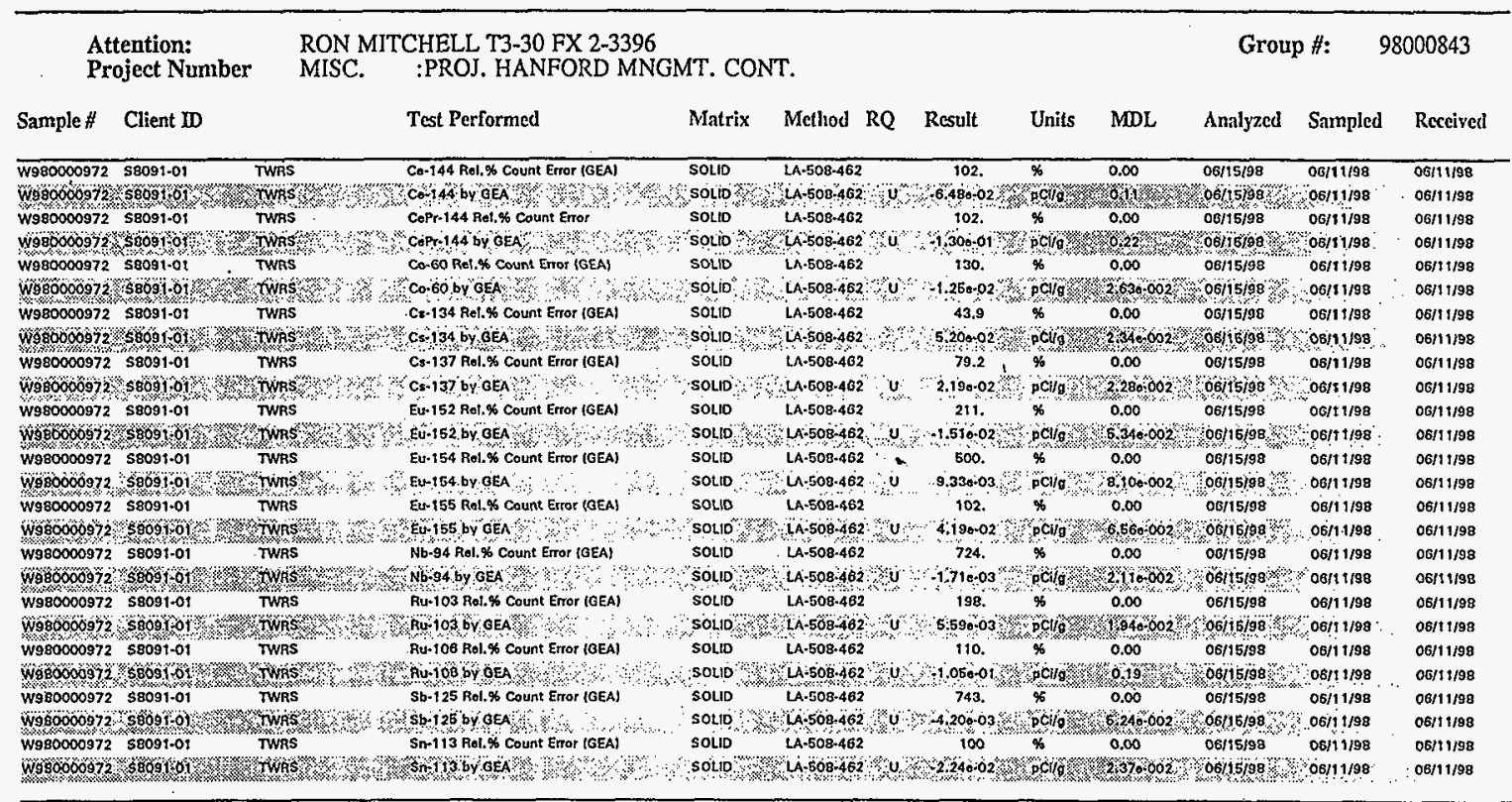

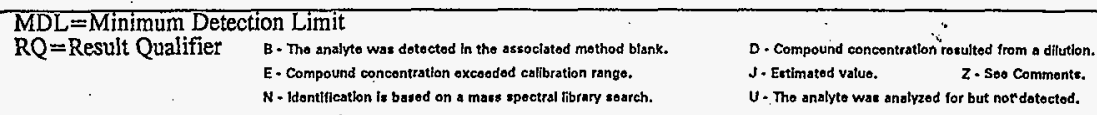

- indleates resuite that havo NOT boen valldated.

J- Ettimated value.
$U$ - The analyte was anelyzed for but nor dotectod.

Woot

PROJECT HANFORD MANAGEMENT CONTRACTORS 
WSCF

\section{ANALYTICAL LABORATORY REPORT}

$\begin{array}{lll}\text { Attention: } & \text { RON MITCHELL T3-30 FX 2-3396 } \\ \text { Project Number } & \text { MISC. } & \text { :PROJ. HANFORD MNGMT. CONT. }\end{array}$

PROJ. HANFORD MNGMT. CONT.

Matrix Method RQ Result Units MDL Analyzed Sampled Reccived

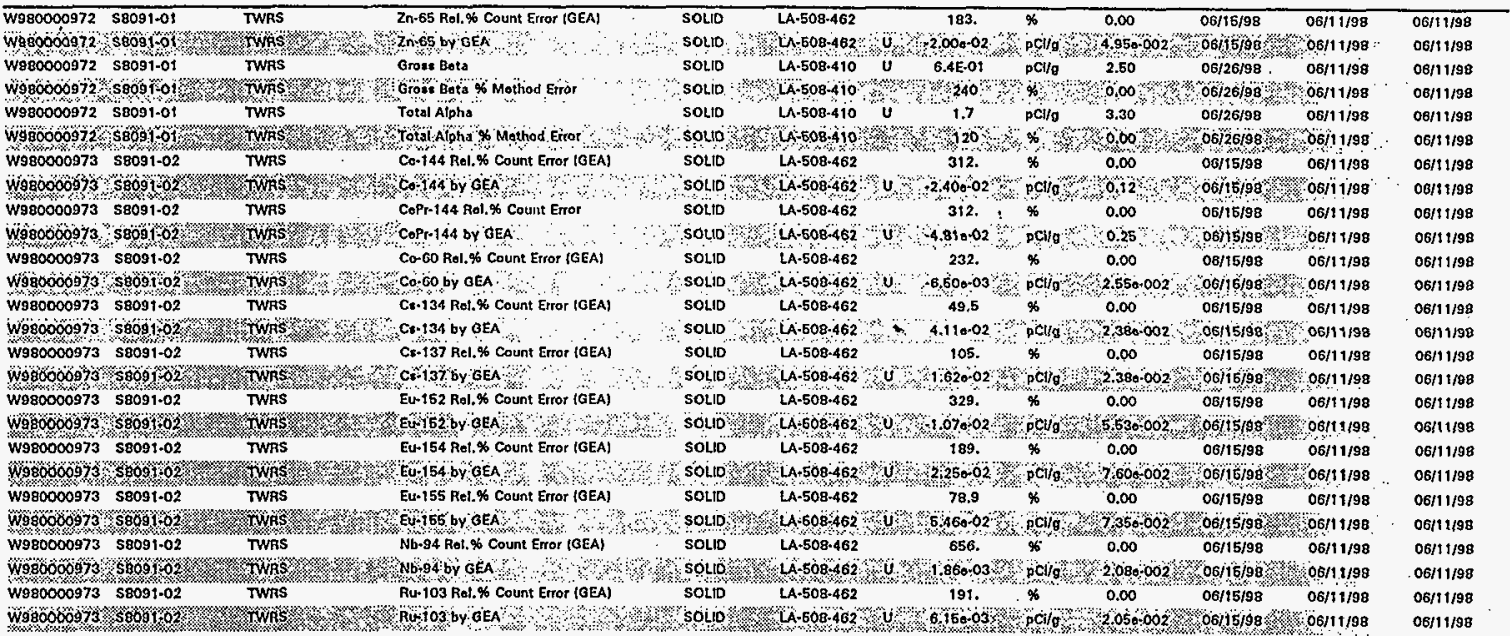

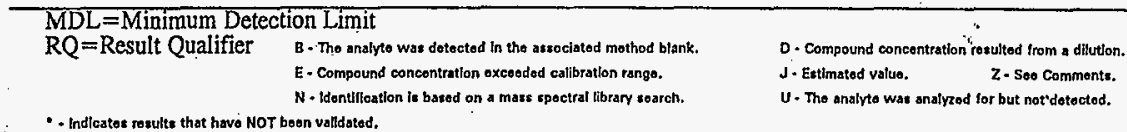

W004

PROJECT HANFORD MANAGEMENT CONTRACTORS 


\section{WSCF}

\section{ANALYTICAL LABORATORY REPORT}

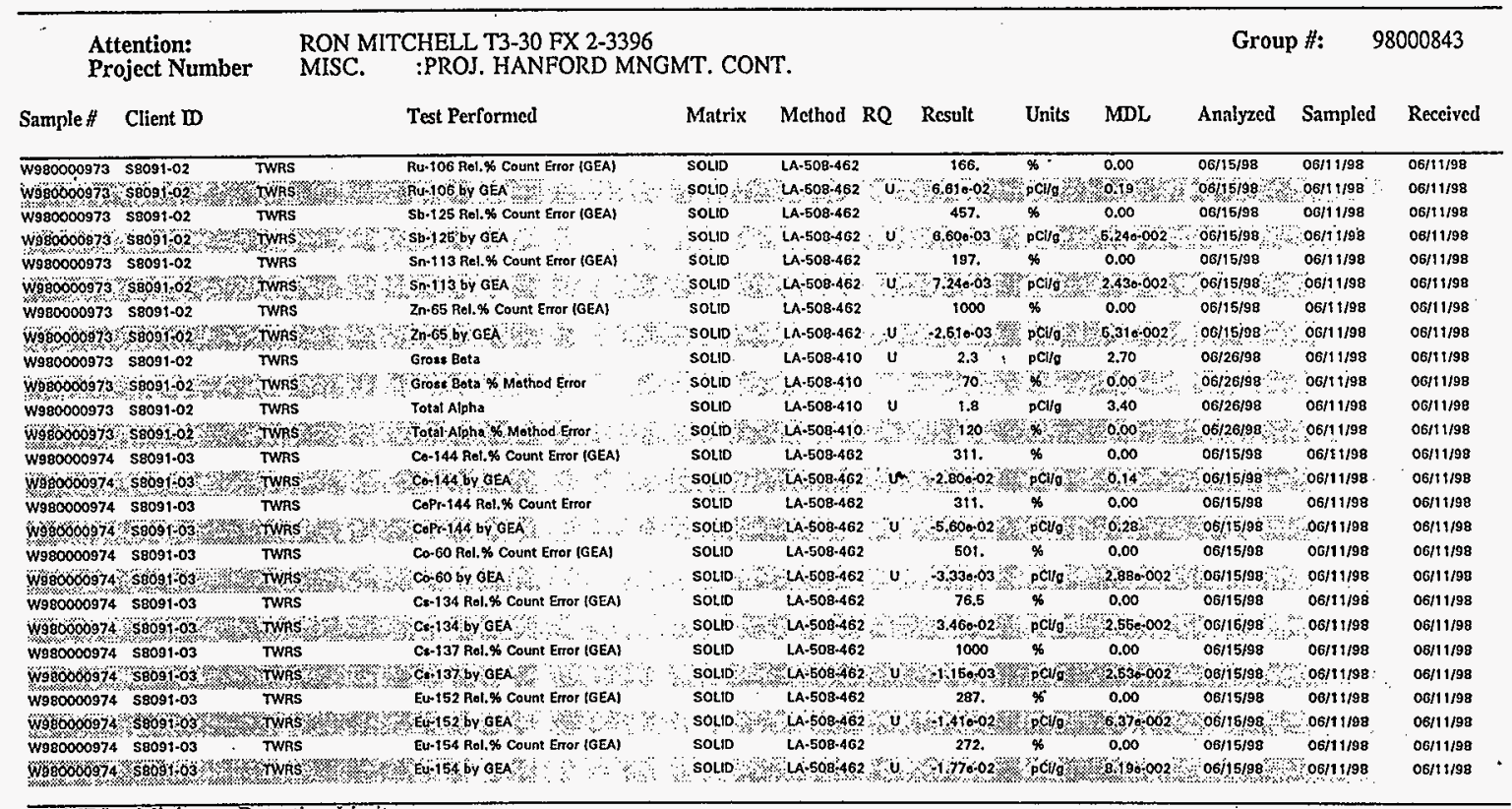

MDL = Minimum Detection Limit

$\mathrm{RQ}=$ Result Qualifier 8 - The analyte was detoctod in tho atsoctated mothod bisnk.

D. Compound coneentration resulted from a dilitition.

E - Compound concentration oxceoded eallibation rango.

$\mathrm{N}$ - Identifleation la based on a mans spectral lbrary soarch.

$J$ - Extimated valuo. Z - 500 Commente.

U. The anslyto was anatyzed for but not'dotocted.

- Indleatoe results that have NOT beon valldated.

W004

PROJECT HANFORD MANAGEMENT CONTRACTORS 


\section{WSCF \\ ANALYTICAL LABORATORY REPORT}

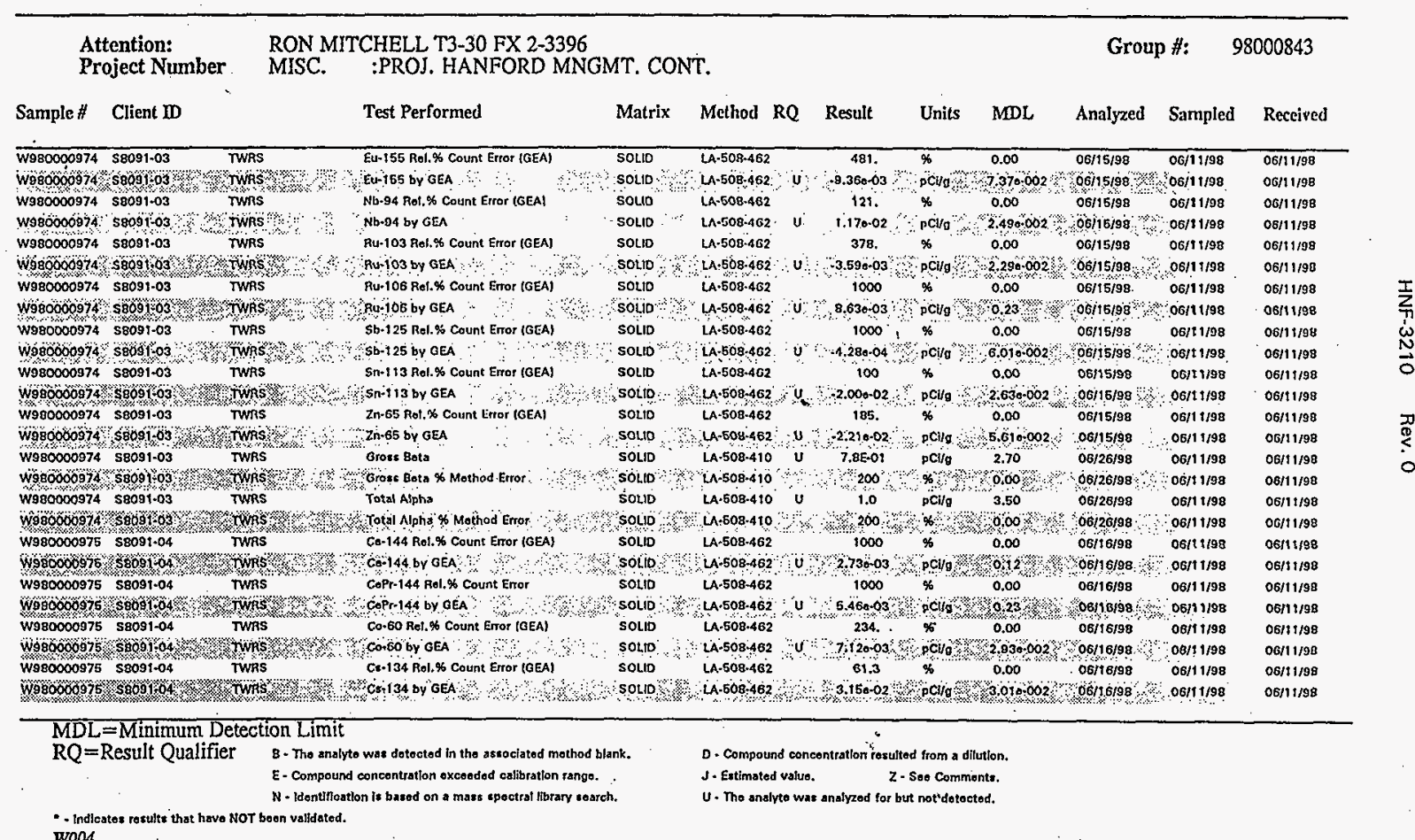

W004

PROJECT HANFORD MANAGEMENT CONTRACTORS 


\section{WSCF}

\section{ANALYTICAL LABORATORY REPORT}

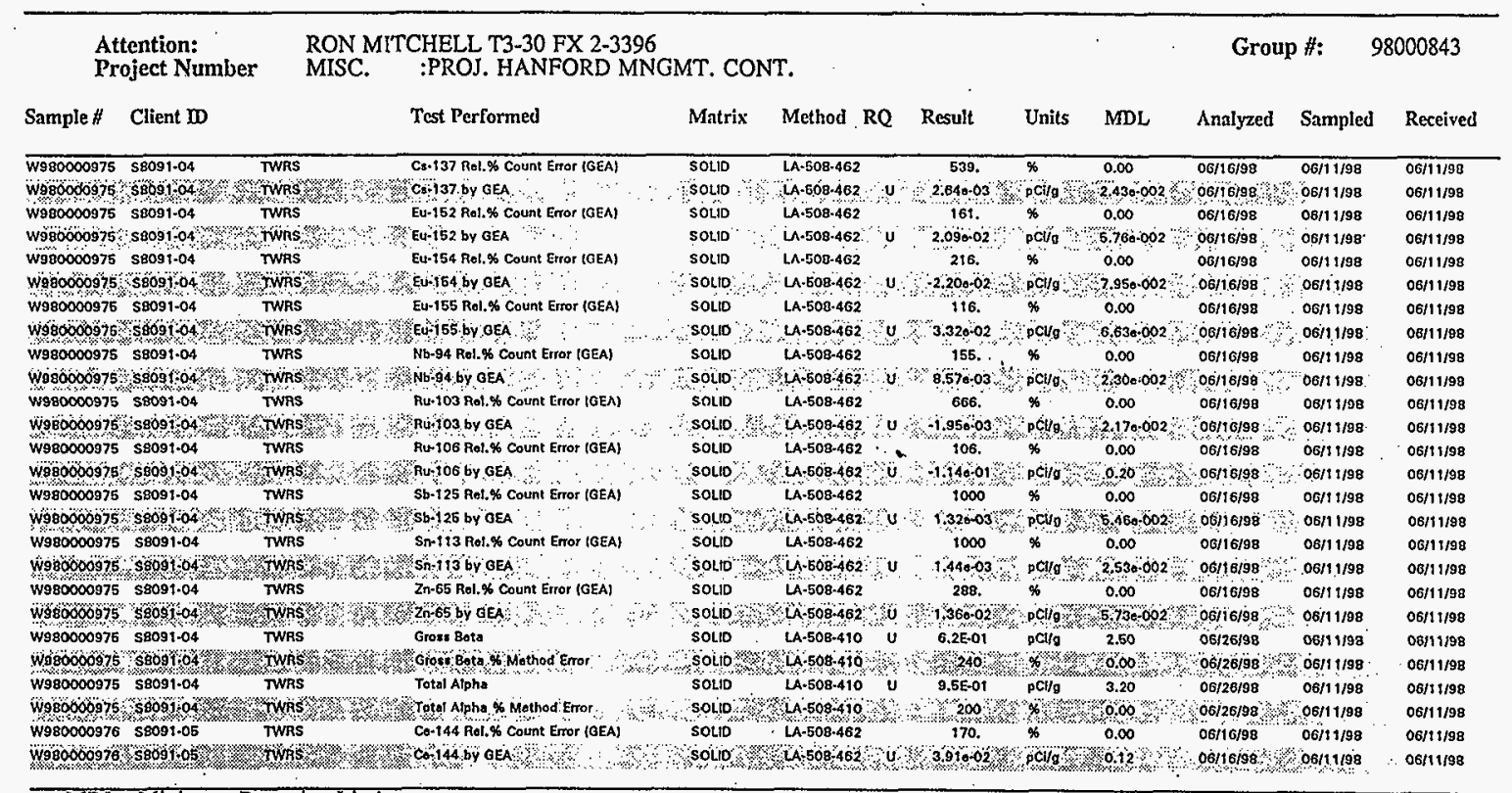

\begin{tabular}{|c|c|c|}
\hline \multicolumn{3}{|c|}{$\mathrm{MDL}=$ Minimum Detection Limit } \\
\hline $\mathrm{RQ}=$ Result Qualifier & B- Tho analve was detected in the associated mothod blank. & D- Compound concontratlon 'asustod from a dilution. \\
\hline & $\begin{array}{l}\text { E- Compound concentration exceeded calibratlon rango. } \\
\mathrm{N} \text { - Identiflcation lz based on a mase xpoctral library woarch. }\end{array}$ & $\begin{array}{l}\text { J - Eotimatod value. Z- Soo Comments. } \\
U \text { - The analyto wat analyzed for but not, detoctod. }\end{array}$ \\
\hline
\end{tabular}

- Inificatos rosults that havo NOT boen valldatod.

W004

PROJECT HANFORD MANAGEMENT CONTRACTORS 


\section{WSCF}

\section{ANALYTICAL LABORATORY REPORT}

Attention: $\quad$ RON MITCHELL T3-30 FX 2-3396

Group \#: $\quad 98000843$

Project Number MISC. :PROJ. HANFORD MNGMT. CONT.

Sample\# Client ID · Test Performed Matrix Method RQ Result Units MDL Analyzed Sampled Received

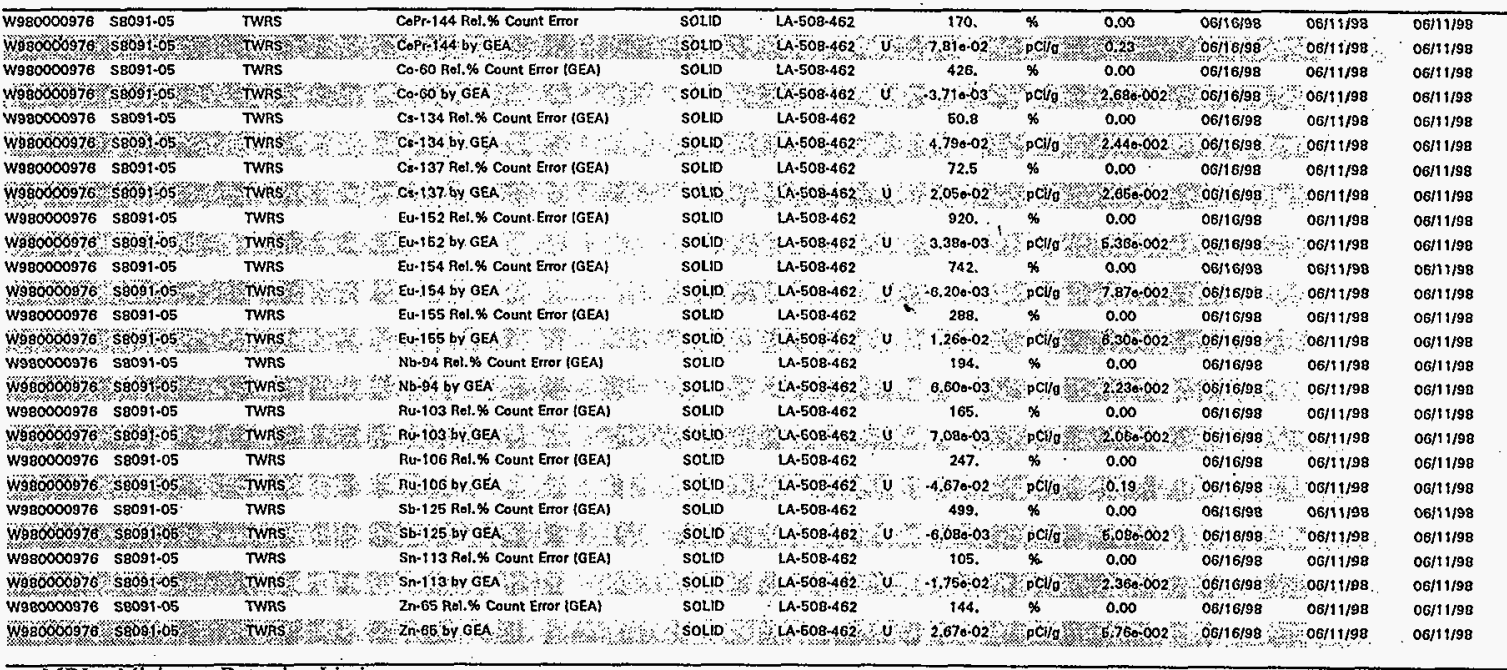

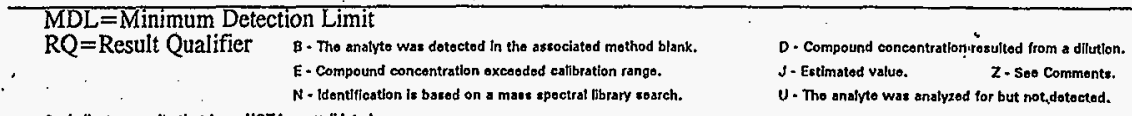

Comments.

- Indieatoe resultu that havo NOT boen validated.

W004

PROJECT HANFORD MANAGEMENT CONTRACTORS 


\section{WSCF \\ ANALYTICAL LABORATORY REPORT}

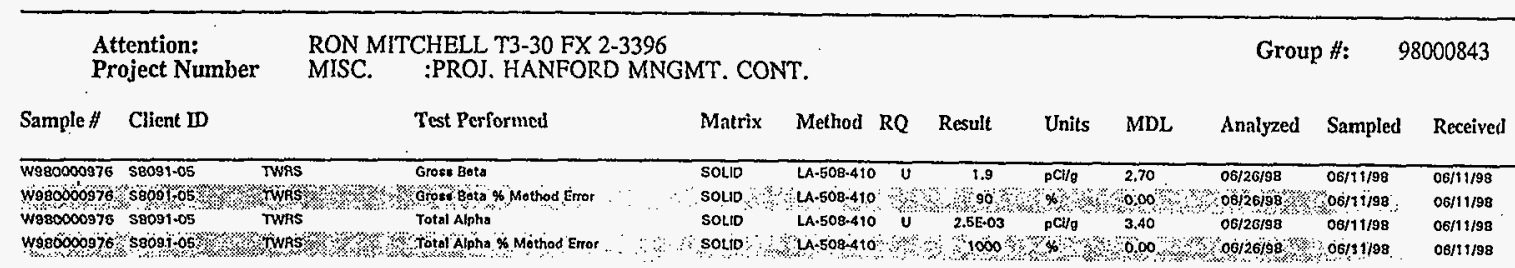

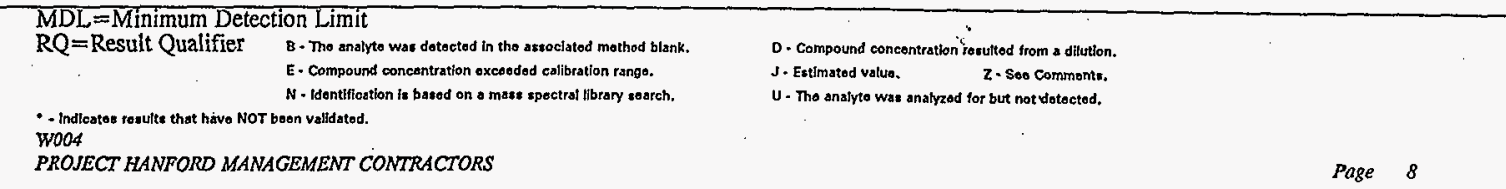


Rev. 0
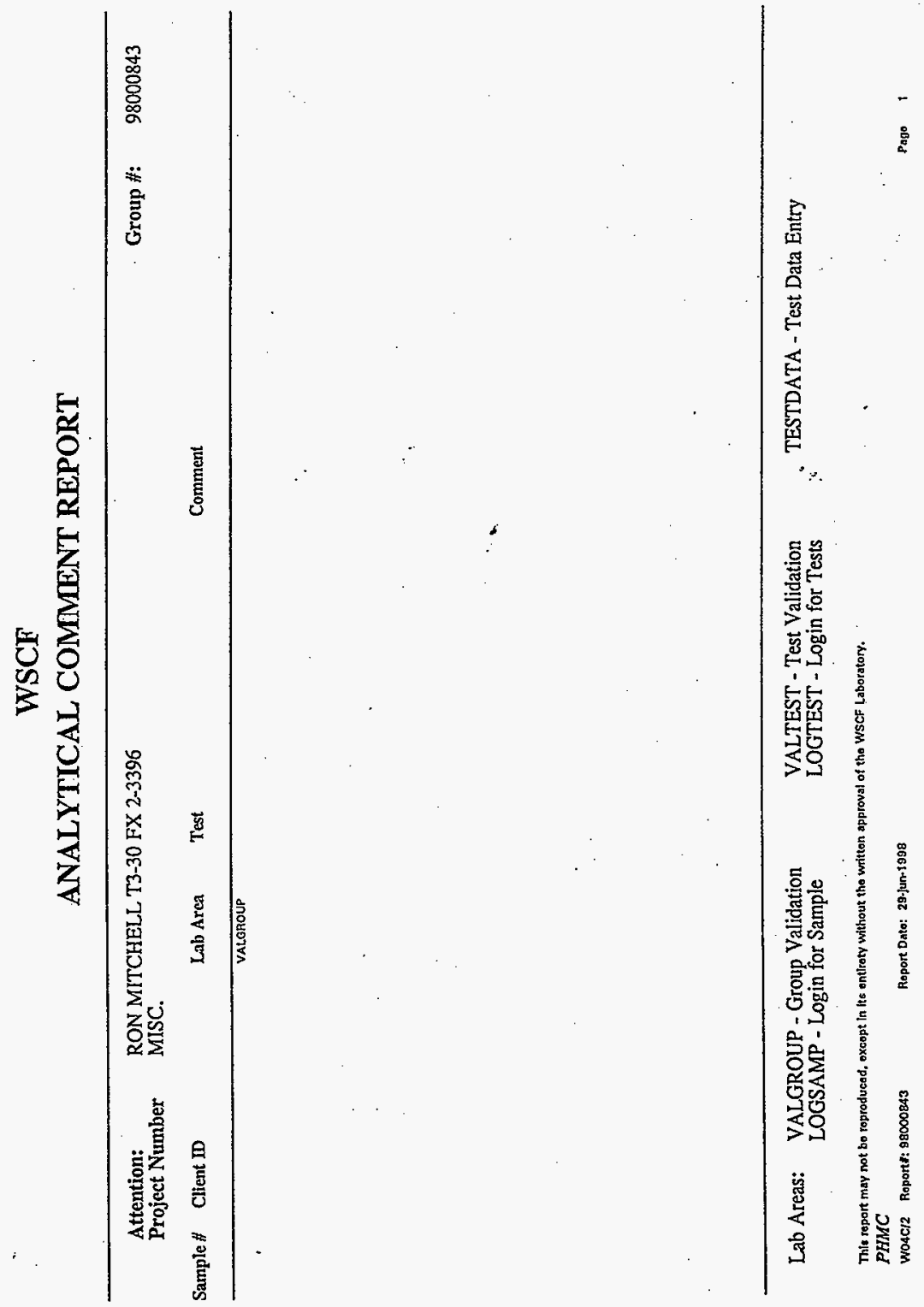


\section{WSCF \\ TENTATIVELY DENTIFIED PEAK REPORT}

Attention:

Project Number

Group \#:

98000843

Sample \# Client $\mathrm{D}$

Test Name

Peak Name

CASH

RT

RQ Result

Units

$\stackrel{?}{\overrightarrow{0}}$

-

$\overrightarrow{0}$

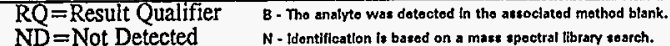

U. The analyte was analyzed for but not detoctod.

This fopert may not to roproduced, excapt in its entiroty without the writton approval of tho wSCF Laboratory. 
HNF-3210 Rev. 0

Attachment $\mathrm{H}$.

Sampling Logbook. 
HNF-3210 Rev. 0

This page intentionally left blank. 


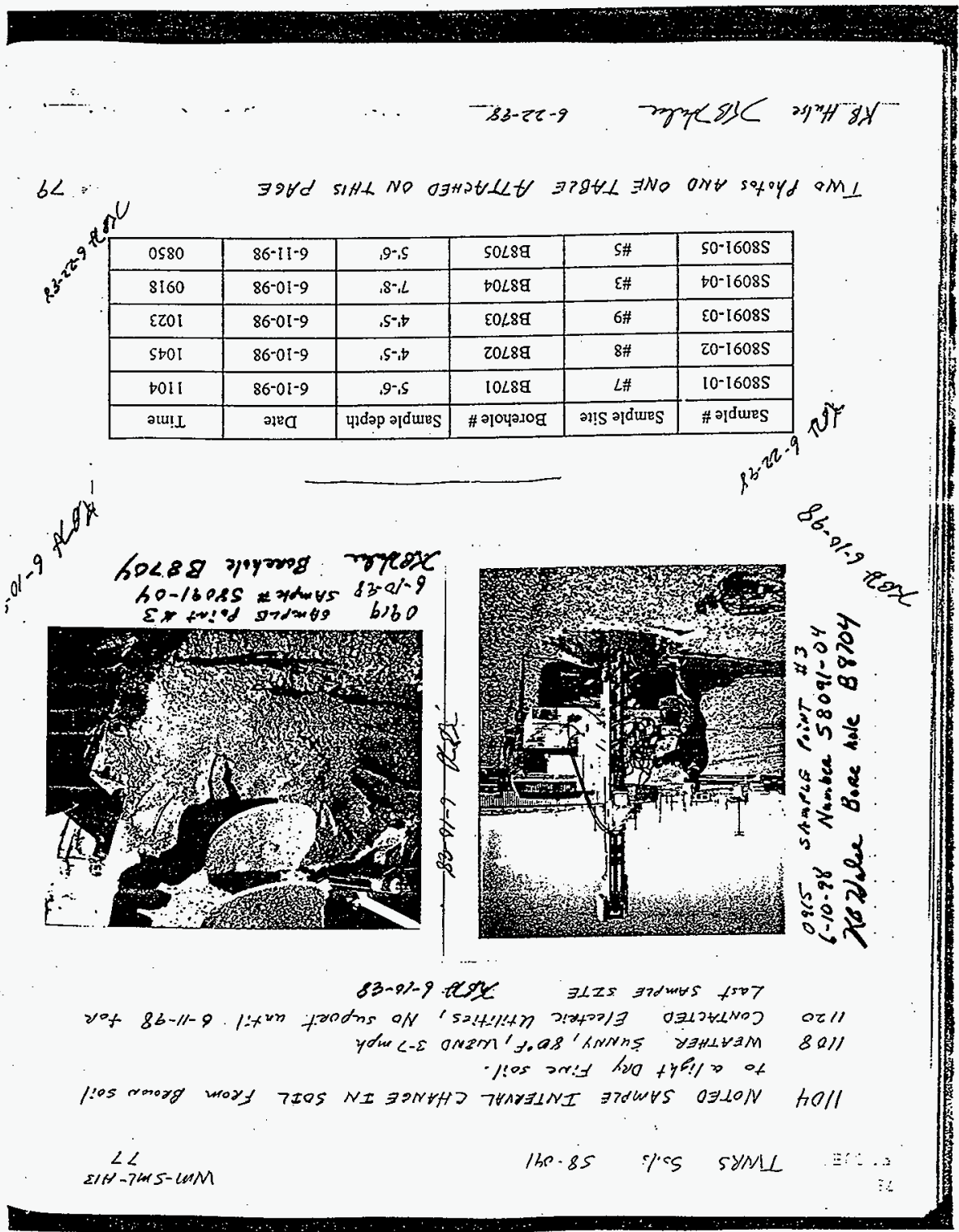



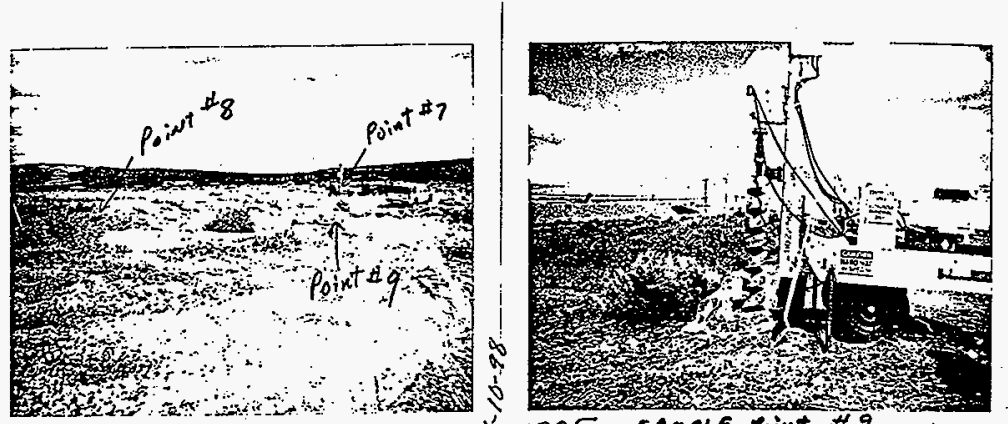

\section{$6-10-98$ \\ TS6 Thlue}

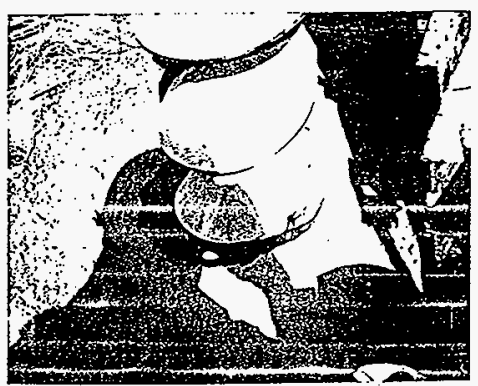

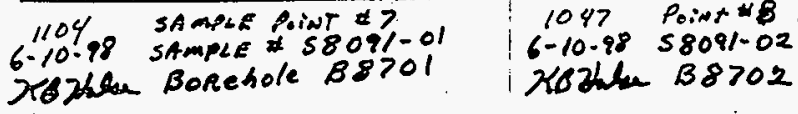

61025 SAmple rivt $\$ 9$

1025
$6 \times 10.88$

SAMPLE PDiUt $\$ 99$
SAMPLE 58091.03

$7602 \mathrm{ke}$

B.ee tale $B 8703$

$$
\text { FUAR PHOTOS ATTAEHEO ON THIS PAGE }
$$

We thats Pis zhen 6-22-58

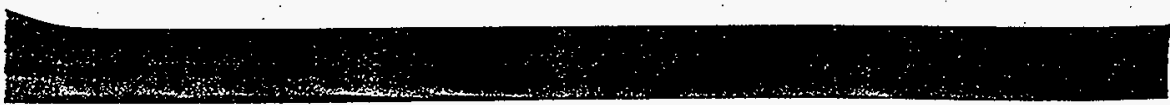


$8 \hat{3}$ PFi: . TWRS SOILs. 58.091 $\therefore W \mathrm{Wm}-5 \mathrm{~mL}-\mathrm{H} / 3$

$\therefore=t:=79$

Soil SAMPLING coNTINUEO: $\quad t=22=926-11-98$

Field Persoval: Ron mitchell

- Dave Seogley

K.B. Hulse

L. Corgarelli
Project Lead

DRilleK + PIC

SAMPLFR

HPT

Reference Documents : Work PACKAGE No. Wr579 SAMPLING DONE TO RCRA PRotocol

0810 ON LOCATION SITE \$5

0822 SET UP ON SAMPLESTTE HS, Blocked ROAd WITh CONES 0827 STARTED OKilling

0841 Rexched 5 Depth and added additimal Fligte to sayple depth of " $S^{\prime}-6$.

0850 SAMPLED OFF BOtIam Quger flite SAMPLE $58091-05$

0855 WEATHER; SUNNY, $722^{\circ}$, WIND 3-T mph NW

0900 OFF SITE NO RADIOACTEYE MATEREAL Detected with Field
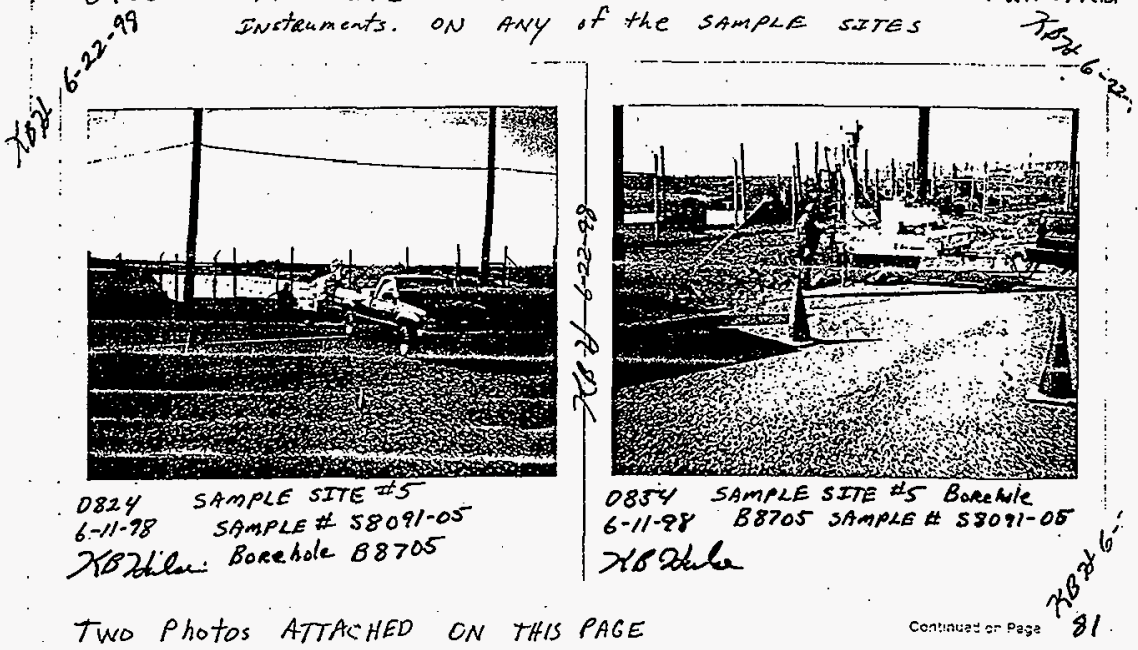

Two Photos ATTACHED ON THIS PAGE

Reac anc unc:s:?:: :

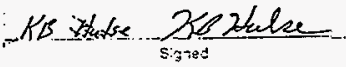

$\frac{6-22-89}{6: 8}$

$\therefore:$

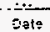




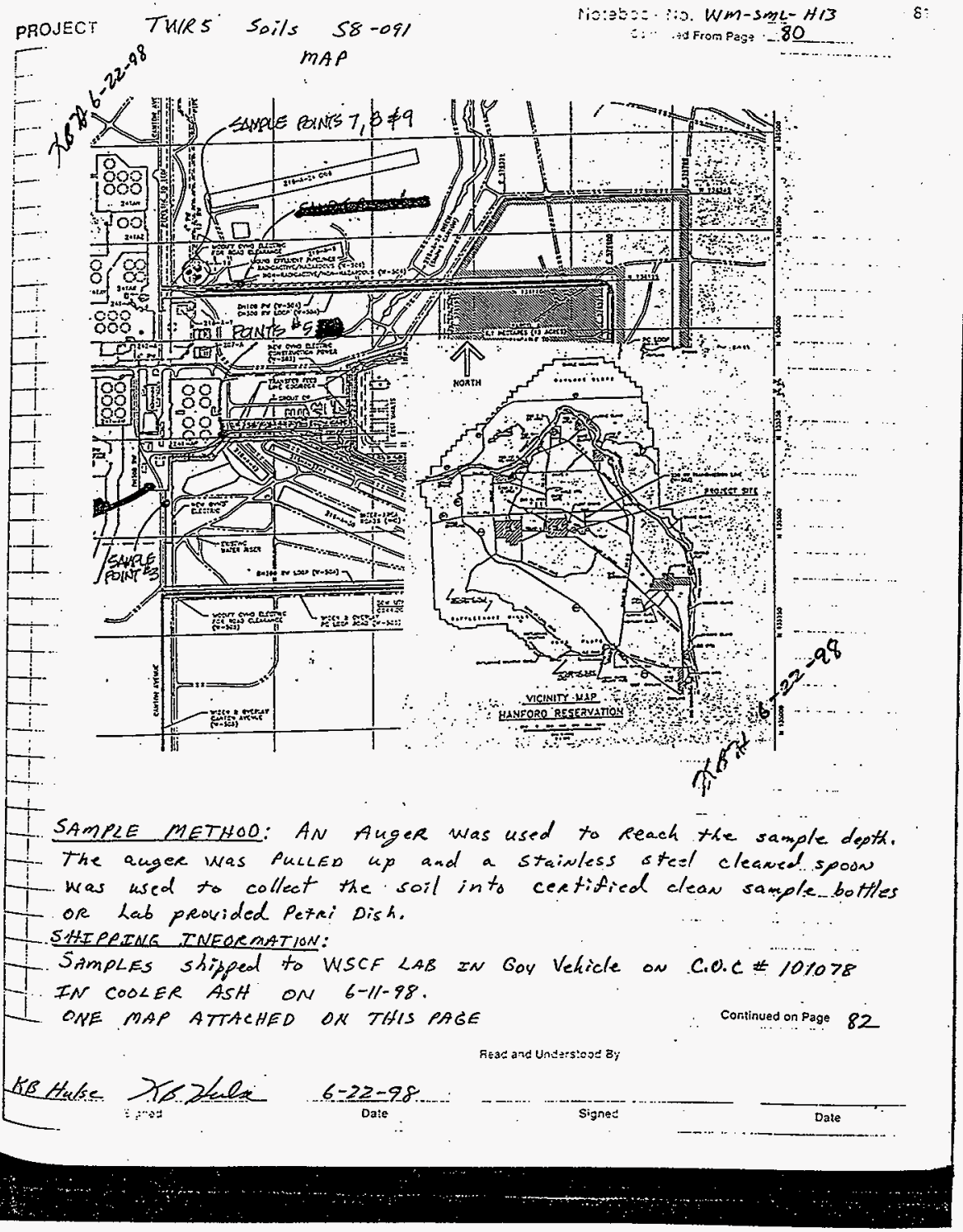


. 82

PROJEC: TWRS soils 58.091 .

Sample Point: Point \#3 Borehole 88704

Sample Matrix: SOlL

\begin{tabular}{|c|c|c|c|c|c|c|}
\hline \multirow[t]{2}{*}{ Sample ID } & Date Collected: & Anslysis & Preservative(s) & Container & Lot $x$ & \multirow{2}{*}{$\begin{array}{l}\text { Laboralory } \\
\text { coc\# }\end{array}$} \\
\hline & \multicolumn{2}{|l|}{ Trme Collected 1} & & & & \\
\hline \multirow[t]{2}{*}{ s80si-04 } & ricoss & \multirow[t]{2}{*}{ Activity Scan (nab Specilte) } & Nene & $20 \mathrm{mLP}$ & \multirow[t]{2}{*}{ N/A } & WSCF \\
\hline & DS18 & & & & & toto78 \\
\hline \multirow[t]{2}{*}{$58091-04$} & Enlores & \multirow{2}{*}{$\begin{array}{l}\text { GEA Ma SPECIFtC) } \\
\text { Tobl NFina Tolal Beta }\end{array}$} & Coot to 4 C & Persolish & \multirow[t]{2}{*}{ - N/A - } & Wsef \\
\hline & 0918 & & & & & 101078 \\
\hline
\end{tabular}

Sample Point: Point $\$ 5$ Borehole $\mathbf{8 8 7 0 5}$

Lead Sampler HULSE, K. B. Sample Matrix: soll,

\begin{tabular}{|c|c|c|c|c|c|c|}
\hline \multirow[t]{2}{*}{ Sample to } & Date Colfected: & \multirow[t]{2}{*}{ Analysts } & Preservatlvats) & Contalner & Lot: & Laborstory \\
\hline & frime collestied & & & & & $\cos :$ \\
\hline \multirow[t]{2}{*}{ s8091-0s } & oniso & \multirow[t]{2}{*}{ Activity Scan (Lab Speciac) } & Norre & $20 \mathrm{~mL} P$ & \multirow[t]{2}{*}{ NA } & WScF \\
\hline & 0250 & & & & & 101078 \\
\hline \multirow[t]{2}{*}{$\$ 8091-05$} & S11ss & \multirow{2}{*}{$\begin{array}{l}\text { GEA (LAS SPECIFIC) } \\
\text { Total Apha Totai Beti }\end{array}$} & \multirow{2}{*}{\multicolumn{2}{|c|}{ Cool to t'c }} & \multirow[t]{2}{*}{$\mathrm{N} / \mathrm{m}$} & wscF \\
\hline & 0850 & & & & & 101078 \\
\hline
\end{tabular}

Sample Point: Point \#7 Boreholé B8701

Lead Sampler HULSE, K. B. Sample Matrix: SolL

\begin{tabular}{|c|c|c|c|c|c|c|}
\hline \multirow{2}{*}{ Srmple to } & \multirow{2}{*}{$\begin{array}{l}\text { Dale Cottectes: } \\
\text { Time Colleted }\end{array}$} & \multirow{2}{*}{ Analysts } & Pracenative(s) & Container & Lot: & Waboratory \\
\hline & & & \multicolumn{3}{|c|}{$\cdot$} & $\operatorname{coc} \theta$ \\
\hline \multirow[t]{2}{*}{ S8091-01 } & citass & \multirow[t]{2}{*}{ Activey Scan (tab Spacific) } & Hore $\cdots . . . .5$ & $20 \mathrm{~mL} P$ & NA & WSSF \\
\hline & 1104 & & & & & 101078 \\
\hline \multirow[t]{2}{*}{$\$ 8091-09$} & onturs & \multirow{2}{*}{$\begin{array}{l}\text { GEA (LAB SPECIFIC) } \\
\text { Tolal Apha Total Bela }\end{array}$} & Coolt to 4'C & & N/A & usce \\
\hline & 1104 & & & & & 101079 \\
\hline
\end{tabular}

Sample Point: Point \#8 Borehole B8702

Lead Semples: HULSE, K. B.

Sample Malrix: solt

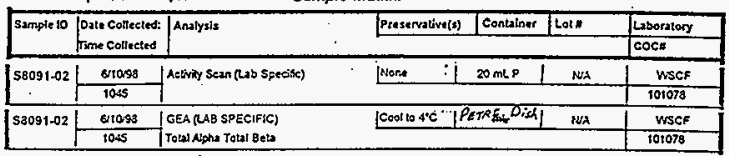

Sample Point: Point $\$ 9$ Borehole 88703

Lead Sampler: HULSE, K. B. Sample Matrix- SOlL

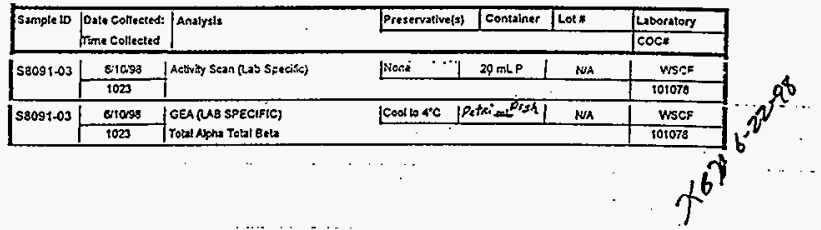

ONE ATTACHMENT ON THIS PAGE

Continued on Page NONE

Read and Understod By

KB Hube 7FbZtalec $\frac{6-22-58}{\text { Date }}$

Signed

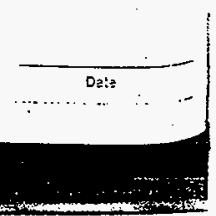




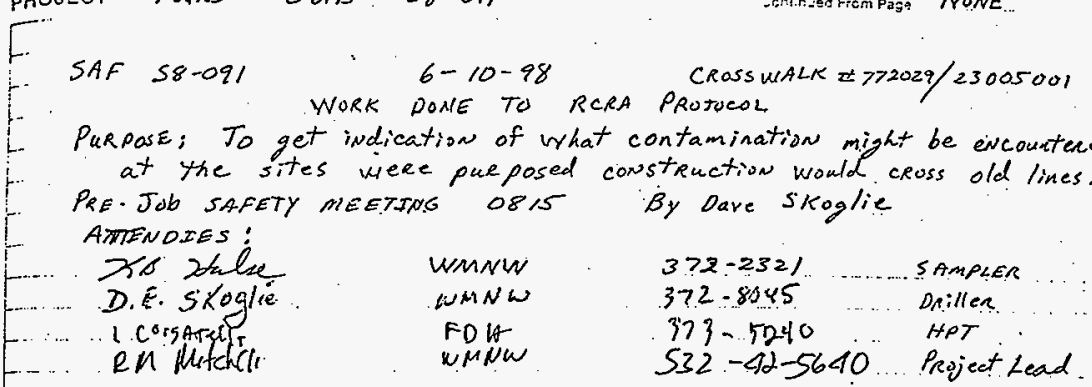

- 0850 seT up on Borehole 2 B8704 sAmplepoint 3 AND stARTED To Deill

0915 Reached sample Dipth of $7^{\prime}$ cleared off auger flights. Dxillitfrer Drilled one more foot, Raised auger to take sample from lower flights.

O918 SAMPLEP, NOTED Change IN soill from a fine saND to a COAASE SAND ATP ON THE BOttom Flights fram where samphe was taken.

WEATHER; SUNNY, 72 OF, WINUD WSWW 5 -10 mph

0930 Filled hole in and moved to Next sITe

1015 SET UP AND STARTED DRilling ON SITE. BORehole "B8703 puint"iq

1020 Reach SAmpLE Depth of 4', eleaned soil back areaund hole

1023 SAMPLED OFF of Bottom Flight of Anger, NOTED a change IN SOil feom SAND TO a very fine ligh edored SAND IN THE SAMRLE INTERVAL $4^{\prime}-5^{\prime}$

Filled IN hole and moved to NEXT BORE HOLE, Weather Surmy. $78^{\circ} \mathrm{F}$, wind 3-10 mph wsw

ON SITE Burehole B8702 pOINT 8 , STARTEO AUGERING Reached SAmpLE Depth \&'

SAMPLED OFF AUGER Flights Near bOttom, SAmpLE INTERVAL 4'S' NOTEO Change IN SOil Near SAmpLE Depth from maist Dintlysuo to dey fine light coloced snid

1050 ON SITE BORehole B8TOI POint H', STARTEO DRilling

- 1101 Reached SAMPLE Depth of $5^{\prime}$, DRilled sAmple INTERVaL $515.75^{\prime}$

:- 1104 SAMPLEO : OFF. OF Bottom:Flight AHGER Continuedon Page 78

: Resy anc Undarstood $B y$

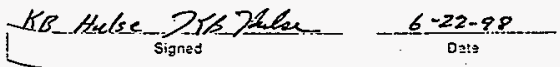

$$
\text { Reje and Undarstood By }
$$




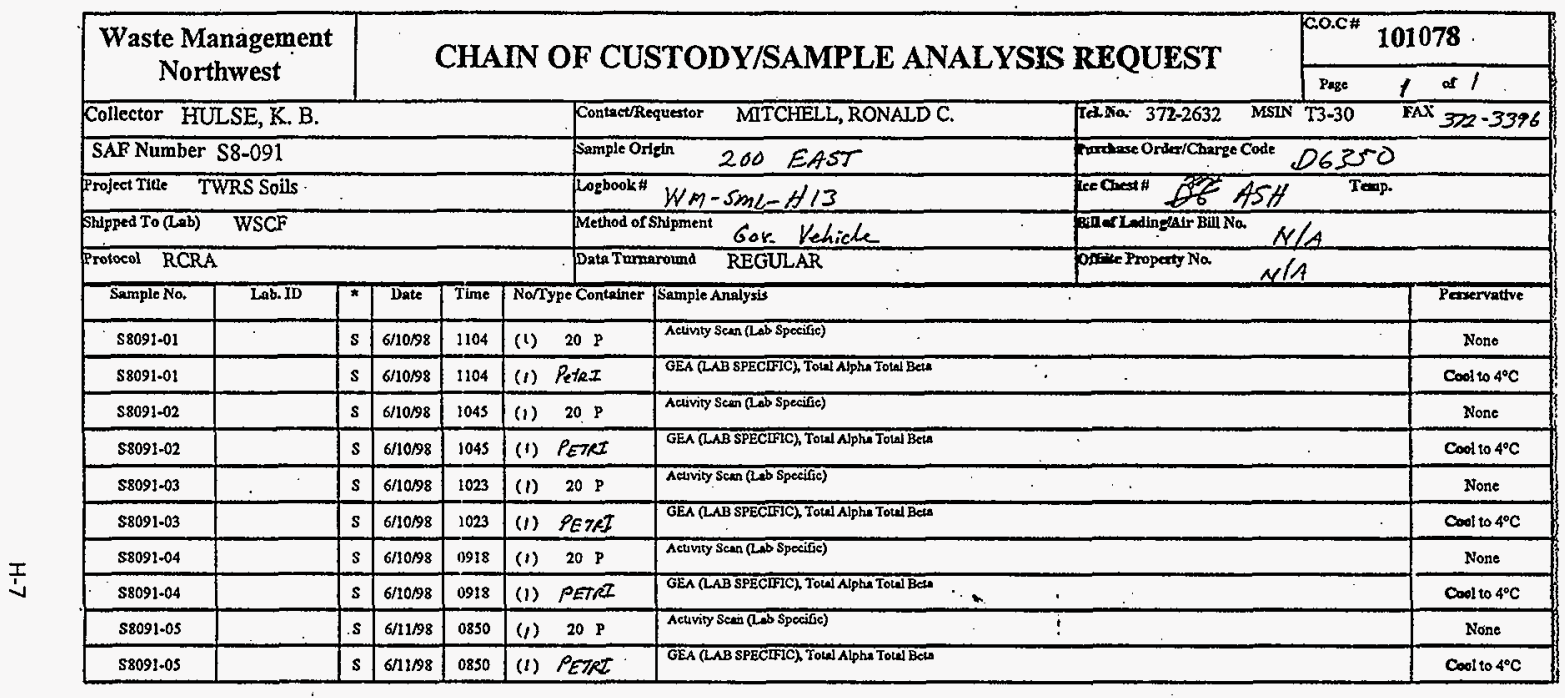

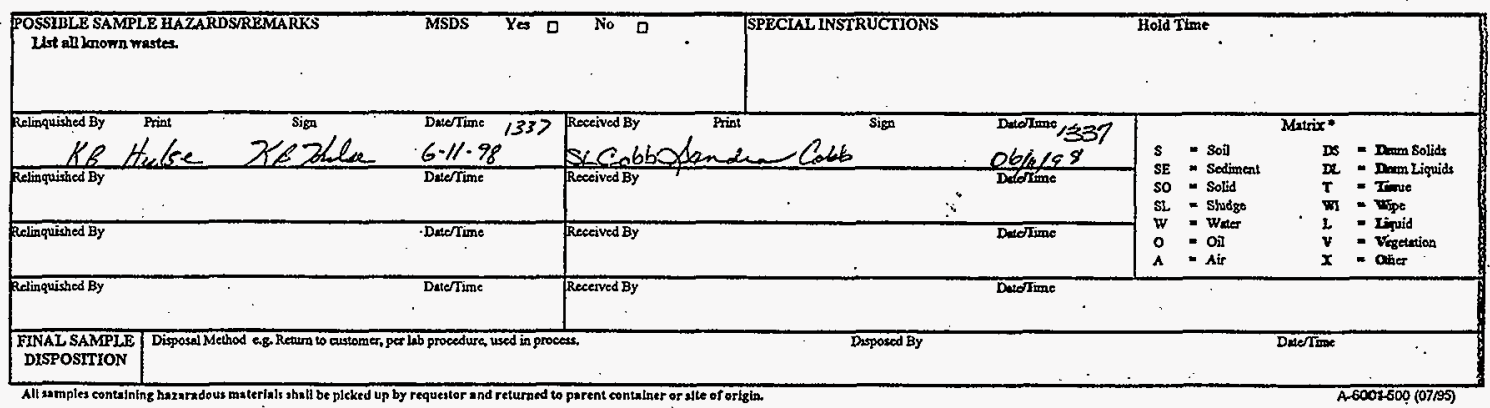


HNF-3210 Rev. 0

This page intentionally left blank. 


\begin{tabular}{|c|c|c|c|c|c|}
\hline \multirow{2}{*}{$\begin{array}{l}\text { To } \\
\text { R. J. Parazin }\end{array}$} & \multirow{2}{*}{\multicolumn{3}{|c|}{$\begin{array}{l}\text { From } \\
\text { R. M. Mitchell }\end{array}$}} & \multicolumn{2}{|c|}{ Page 1 of 1} \\
\hline & & & & \multicolumn{2}{|c|}{ Date $09 / 11 / 98$} \\
\hline \multirow{2}{*}{\multicolumn{4}{|c|}{$\begin{array}{l}\text { Project Title/Work Order } \\
\text { W-519 Infrastructure Characterization/D6350 }\end{array}$}} & \multicolumn{2}{|c|}{ EDT No. } \\
\hline & & & & \multicolumn{2}{|c|}{ ECN No. NA } \\
\hline Name & MSIN & $\begin{array}{l}\text { Text } \\
\text { With All } \\
\text { Attach. }\end{array}$ & Text Only & $\begin{array}{l}\text { Attach./ } \\
\text { Appendix } \\
\text { Only }\end{array}$ & $\begin{array}{c}\text { EDT/ECN } \\
\text { Only }\end{array}$ \\
\hline $\begin{array}{l}\text { J. J. Dorian } \\
\text { D. L. Fort (3 copies) } \\
\text { P. A. Haine } \\
\text { T. R. Hoertkorn } \\
\text { A. R. Johnson } \\
\text { B. M. Markes } \\
\text { R. M. Mitche11 (5 copies) } \\
\text { T. H. Mitche11 } \\
\text { D. J. Moak } \\
\text { R. J. Parazin (3 copies) } \\
\text { S. P. Reidel } \\
\text { D. E. Skogi ie } \\
\text { K. J. Young } \\
\text { Document Processing Center }\end{array}$ & $\begin{array}{l}\mathrm{H} 1-13 \\
\mathrm{R} 3-47 \\
\mathrm{R} 3-47 \\
\mathrm{~B} 4-55 \\
\mathrm{H} 1-13 \\
\mathrm{H} 1-13 \\
\mathrm{H} 1-13 \\
\mathrm{H} 9-02 \\
\mathrm{H} 1-11 \\
\mathrm{R} 3-47 \\
\mathrm{~K} 6-81 \\
\mathrm{H} 1-13 \\
\mathrm{H} 1-12 \\
\mathrm{~A} 3-88\end{array}$ & $\begin{array}{l}x \\
x \\
x \\
x \\
x \\
x \\
x \\
x \\
x \\
x \\
x \\
x \\
x \\
x\end{array}$ & & & \\
\hline Centrai Files & $B 1-07$ & $x$ & & & \\
\hline
\end{tabular}

